Article

\title{
Challenges in the Assessment of Mining Process Water Quality
}

\author{
Thi Minh Khanh Le ${ }^{1, *} \mathbb{C}$, Hanna Miettinen ${ }^{2} \mathbb{C}^{-}$, Malin Bomberg ${ }^{2}\left(\mathbb{D}\right.$, Nóra Schreithofer ${ }^{1}$ \\ and Olli Dahl ${ }^{1}$ \\ 1 Department of Bioproducts and Biosystems, School of Chemical Engineering, Aalto University, \\ Vuorimiehentie 1, 02150 Espoo, Finland; nora.schreithofer@aalto.fi (N.S.); olli.dahl@aalto.fi (O.D.) \\ 2 VTT Technical Research Centre of Finland Ltd., Tietotie 2, FI-02044 VTT Espoo, Finland; \\ hanna.miettinen@vtt.fi (H.M.); malin.bomberg@vtt.fi (M.B.) \\ * Correspondence: thi.5.le@aalto.fi
}

Received: 26 August 2020; Accepted: 21 October 2020; Published: 23 October 2020

\begin{abstract}
The changes in water quality owing to recirculation of water in mineral processing plants can compromise the plant performance as well as maintenance needs. Therefore, mining process water quality assessment is becoming critical. Nevertheless, very few studies have investigated the suitability of the current analysis methodology practiced in certified laboratories for evaluating mining process water quality. This article presents two case studies to highlight the major issues encountered when performing sampling for physicochemical and chemical parameters in process water at two European mine sites using procedures from two certified laboratories. In addition, microorganisms were shown to be abundant in process waters and likely affect the mining water chemistries. However, the protocols used for microbial studies are not optimal for mining process samples, and need to be improved. The results showed difficulties in providing satisfactory results when analyzing control samples. Additionally, the analysis results presented a strong imbalance in TDS and sulfur compounds. Several potential causes associated with the poor quality of the analysis results have been outlined with a specific focus on the preservation methods. A literature review on the degradation of thiosalts suggested that the current preservation procedures are not suitable for preserving sulfur compounds. Moreover, the results indicated that the water matrix strongly influenced the validity of the chosen analysis method. In conclusion, the analysis methods should be customized for the different mining water matrix types in order to ensure the accuracy and reproducibility of the results.
\end{abstract}

Keywords: water management in mining; mining water analysis; thiosalts analysis; water sampling; water preservation; bacterial analysis for mining water

\section{Introduction}

The existing water quality monitoring systems in the mining industry are mainly focused on fulfilling the environmental regulations set on the environmental and operational permits of the mines. Most of the effort of water quality monitoring is focused on investigating the effect of mining water on the surrounding environment [1]. As a consequence, the analysis and sampling methodology is mostly developed for answering the needs of monitoring the discharge effluents during the mine's lifetime and after its closure [2]. The list of physicochemical parameters, chemical elements, and compounds that need to be monitored are provided by government regulations $[3,4]$. The procedure for sampling is also well documented [5-7]. Nevertheless, due to the potential effects of water quality on the flotation process performance and plant maintenance needs, the trend is now changing. The monitoring of water quality for controlling the plant's performance and maintenance purposes is becoming one 
of the biggest challenges in terms of water management in mining [8]. Ore type and water quality are proven as major parameters that can affect the concentrator performance, particularly the froth flotation [9-11]. The literature indicates that the variation of organic and inorganic compounds and physicochemical parameters of water, as well as microorganisms, can have detrimental effects on the recovery of valuable minerals during the flotation [12-14]. Therefore, the methodology for water quality assessment needs to be developed and optimized not simply for fulfilling the environmental regulations but also for process performance optimization and control purposes. Such conditions mean that the sampling methodology should be revised in such a way that the water quality data and other parameters such as mineralogy, operating conditions, and plant performance could be linked and used together for controlling and adjusting the process. In addition to the discharged effluents, both the process water and the water inside the mine must be monitored [8]. The data must be high frequency, preferably online, or in situ analysis/measurements, and cover a number of water quality parameters that have potential impacts on the plant performance [15]. However, this approach raises several challenges.

The first challenge is from a technical point of view. Plant water composition is largely different from discharged effluents, even though they are all classified as mining water. In most cases, the discharged waters are treated before disposal [16]. Therefore, their water matrices are characterized by low total dissolved solids (TDS) and high stability due to the low concentration of reactive compounds. However, the waters/slurries inside the process are characterized by high TDS, high suspended solids, and particularly high reactivities [17]. As a result of the matrix effects, the sampling and analytic procedures that are validated for mining effluent waters might not be suitable for analyzing mining process waters.

The second challenge is that only a few water quality parameters can be monitored in real time. The majority of the parameters of interest that characterize the water quality are still determined by laboratory analysis [8]. Moreover, due to the reactivity of the slurry, the process water characteristically contain a high level of unstable compounds such as reduced sulfur compounds, thiosalts, and reagent decomposition products. In addition, potentially present active microorganisms may affect the chemical parameters in relatively short time periods if not taken into account. This implies that the nature of the mining process water is likely to change during transportation and storage before the actual laboratory analysis commences. Thus, preservation and stabilization of the samples are necessary steps before sending water for analysis. Several chemical and physical methods for stabilizing water samples are found in the literature such as the addition of stabilization chemical compounds, filtration, nitrogen purging, cooling, and freezing [5]. However, the preservation/stabilization of the water is usually not fully considered as an important step before the laboratory analysis procedure. The lack of a suitable preservation/stabilization procedure included in the sampling protocol results in a major problem, where samples are sent to the analysis laboratory without any suitable stabilization/preservation.

Additionally, the indigenous microorganisms in mining processes may also affect the water quality and plant performance [18]. Microorganisms have numerous ways to interact with minerals and surfaces [19]. To study the microorganisms in these environments, and prevent, e.g., fouling, the microorganisms and/or their nucleic acids need to be detached from the mineral particles, which would otherwise hamper downstream analyses.

Finally, unlike discharged waters, no clear guidelines define the number and the type of parameters that must be monitored for process waters. The different parameters of interest are mine and process specific. Generally, to understand the full effect of water quality on plant performance, a long-term, regular sampling campaign with an extensive number of parameters and compounds is required. Additionally, samples from critical locations of the process such as incoming process water, mill discharge, feed to flotation, feed to the cleaning stages, tailings, etc., must be taken and analyzed to establish the relation between water quality and the flotation performance at different stages $[13,20,21]$. Thus, the challenges of water evaluation stem from (1) the high number of samples 
that should be prepared, (2) the high volume of samples needed for the full analysis, and (3) the high cost of the analysis.

Before this study, the authors investigated several analysis standards used for analyzing mining waters. The results showed that none of these standards were developed specifically to analyze mining process waters. Therefore, the main objective of our study was to investigate the suitability and accuracy of the current sampling and analysis methodology for mining water with samples from two European mine sites (denoted in this paper as Mine 1 and Mine 2). Mine 1 is located in southern Europe and Mine 2 in a Nordic country. The sample preparation and preservation were performed according to the procedures of laboratories suggested by the mine sites and contracted by the project.

This paper highlights the low quality of part of the analysis results as well as the inappropriate methodology for preserving and analyzing the complex and unstable water matrix of the mining process waters. Additionally, this paper discusses the possible remedies to these low-quality results and suggests several modifications that can be considered to improve the methods and results of the analysis.

\section{Materials and Methods}

\subsection{Particularities of the Mine Sites}

The characteristics of Mine 1 and Mine 2 in terms of ore type, processing method, tailing deposition method, water circuit, and water matrix are detailed in Table 1. The nature of the processed ore types, climate, and type of water circuit have significant effects on the water matrix properties of each mine site. Due to the seasonal variation of the water quality of Mine 2, two sampling campaigns were performed for this mine. One sampling campaign was conducted during wintertime (February), whilst the other was conducted during summertime (August).

Table 1. Characteristics of Mine 1 and Mine 2.

\begin{tabular}{|c|c|c|}
\hline Parameter & Mine 1 & Mine 2 \\
\hline Location & - South of Europe & - Nordic countries \\
\hline Climate & - Mediterranean & - $\quad$ Subarctic \\
\hline Ore type & $\begin{array}{l}\text { - } \quad \text { VMS } \\
\text { - } \quad \text { High pyrite content } \\
\text { - Strong variation of mineralogy as a } \\
\text { function of the ore bodies }\end{array}$ & $\begin{array}{l}\text { - } \quad \text { Low sulfide grade deposit } \\
\text { - } \quad \text { Silicate minerals as the major phase }\end{array}$ \\
\hline Bulk mineralogy & $\begin{array}{l}\text { Plant 1: Py: } 86 \% \text {, Ccp: } 5 \%, \text { Gn: } 0.1 \%, \text { Sp: } \\
\text { 1\%, Apy: } 1.4 \% \text {, silicates and other: } 6.5 \% \\
\text { Plant 2: Py: } 86 \% \text {, Ccp: } 0.9 \% \text {, Gn: } 0.1 \%, \text { Sp: } \\
\text { 8\%, Apy: } 1.5 \% \text {, silicates and other: } 3.5 \%\end{array}$ & $\begin{array}{l}\text { Ccp: } 0.6 \%, \text { Pn: } 0.49 \% \text {, Cub: } 0.34 \% \text {, } \\
\text { Po: } 1 \% \text {, Py: } 0.7 \% \text {, silicates and other: } 96 \%\end{array}$ \\
\hline Processing method & - Two separate flotation plants & - $\quad$ Sequential circuit \\
\hline Tailing deposit method & - $\quad$ Paste deposition & - Conventional wet tailings pond \\
\hline Water circuit & $\begin{array}{l}\text { - } \quad \text { Short water cycle } \\
\text { - } \quad \text { Short resident time in the TSF }\end{array}$ & $\begin{array}{l}\text { - Long water cycle } \\
\text { - } \quad \text { Long residence time in the TSF }\end{array}$ \\
\hline $\begin{array}{l}\text { Water matrix } \\
\text { characterization }\end{array}$ & $\begin{array}{l}\text { - } \quad \text { High TDS (up to } 10000 \mathrm{mg} / \mathrm{L} \text { ) } \\
\text { - } \quad \text { High concentration of thiosalts } \\
\text { - } \quad \text { Gypsum saturated }\end{array}$ & $\begin{array}{l}\text { Cyclic variations in } \\
\text { dissolved/suspended solid content due } \\
\text { to the formation of an ice cap in the } \\
\text { tailing pond during winter }\end{array}$ \\
\hline
\end{tabular}

VMS: volcanic massive sulfide, TSF: tailings storage facilities, TDS: total dissolved solids, Py: pyrite, Ccp: chalcopyrite, Gn: galena, Sp: sphalerite, Apy: asenopyrite, Pn: penlandite, Cub: cubanite, Po: pyrrhotite. 


\subsection{Sampling Surveys}

The water sampling was designed to evaluate three major aspects of the water, namely the physicochemical, chemical, and biological properties.

In terms of the physicochemical properties, the following parameters were measured in situ: specific conductance (SPC), $\mathrm{pH}$, oxidation-reduction potential (ORP), dissolved oxygen (DO), turbidity, and temperature. ORP measurements used $\mathrm{Ag} / \mathrm{AgCl}$ as the reference electrode. ORP and $\mathrm{pH}$ were also measured in the laboratory to characterize the degradation of the sample during transportation and storage. To complete a pulp physicochemical property characterization, slurry samples (around $10 \mathrm{~L}$ each) were taken from the streams of interest and placed into buckets. The pulp sample was immediately measured after the sampling with the YSI ProDSS multiparameter probe (YSI, Xylem Inc., Yellow Springs, $\mathrm{OH}, \mathrm{USA}$ ) whilst the pulp was gently stirred. The probe recorded the readings for $10 \mathrm{~min}$ to make sure that equilibrium was obtained. All the probes were checked and calibrated if needed before use. Other physicochemical measurements such as total suspended solids (TSS), total organic carbon (TOC), dissolved organic carbon (DOC), dissolved inorganic carbon (DIC), total inorganic carbon (TIC), total carbon (TC), chemical oxygen demand (COD), and biological oxygen demand (BOD) were analyzed by the contracted commercial analytical laboratory. A two-liter slurry sample was drawn from the same container and preserved at $4{ }^{\circ} \mathrm{C}$ for the mentioned physicochemical analyses.

An extra two-liter sample was drawn from the $10 \mathrm{~L}$ slurry sample bucket and prepared for chemical analysis. The preparation procedure followed the laboratory recommendation and is presented in Table 2. What stands out in the table is that the practices for sample preservation of the two laboratories concerning this study differ greatly. These differences can be explained in part by the analysis methods used by each laboratory. Methods and standards used, as recommended by the certified laboratories, for analysis are shown in Appendix A, Table A1. In general, the laboratory used by Mine 2 only required filtration and cold storage as preservation methods while the laboratory used by Mine 1 required some further stabilization with reagents. Due to the high content of solids in the slurry, a direct filtration at $1.6 \mu \mathrm{m}$ and $0.45 \mu \mathrm{m}$ was impossible. The filtration was therefore performed in several stages. The first stage was a pre-filtration at 12-15 $\mu \mathrm{m}$ (qualitative filter paper, 415, VWR International, Helsinki, Finland), the second stage was a filtration at $1.6 \mu \mathrm{m}$ (VWR, International, Helsinki, Finland), and the last stage was the filtration at $0.45 \mu \mathrm{m}$ with syringe filters (VWR, International, Helsinki, Finland).

Table 2. Preservation methods for preserving different compounds/elements according to two chosen laboratories.

\begin{tabular}{|c|c|c|}
\hline Parameter & Laboratory of Mine 1 & Laboratory of Mine 2 \\
\hline $\mathrm{pH}, 25^{\circ} \mathrm{C}$ & \multirow{3}{*}{ No filtration, cool preservation } & \multirow{2}{*}{ In situ measurements } \\
\hline Conductivity, $25^{\circ} \mathrm{C}$ & & \\
\hline TDS & & Filtering $1.6 \mu \mathrm{m}$ \\
\hline TSS & Decant & Decant \\
\hline Tot. Alkalinity, $\mathrm{CO}_{3}{ }^{2-}$ and $\mathrm{HCO}_{3}^{-}$ & Cool & Not applicable (N.A) \\
\hline TOC, TIC, TC, DOC & $\begin{array}{c}\text { Filtering } 1.6 \mu \mathrm{m}+ \\
1<\mathrm{Ph}<2 \text { with } \mathrm{H}_{2} \mathrm{SO}_{4}\end{array}$ & Filtering $1.6 \mu \mathrm{m}+\mathrm{cool}$ \\
\hline BOD & N.A & Slurry \\
\hline Thiosalts, polythionates & \multirow{4}{*}{ Filtering $1.6 \mu \mathrm{m}+$ Cool } & N.A \\
\hline Thiosulfate & & \multirow{3}{*}{ Filtering $1.6 \mu \mathrm{m}+\mathrm{cool}$} \\
\hline Sulfate & & \\
\hline Chloride & & \\
\hline
\end{tabular}


Table 2. Cont.

\begin{tabular}{ccc}
\hline Parameter & Laboratory of Mine 1 & Laboratory of Mine 2 \\
\hline Sulfite & $\begin{array}{c}\text { Filtering } 1.6 \mu \mathrm{m}+ \\
1 \mathrm{~mL} \text { of EDTA at } 1 \%+\text { cool }\end{array}$ & N.A \\
\hline Sulfide & $\begin{array}{c}\text { Filtering } 1.6 \mu \mathrm{m}+2 \mathrm{~mL} \text { of } \mathrm{Zinc} \\
\text { Acetate } 8.5<\mathrm{pH}<9.0 \text { with } \mathrm{NaOH}\end{array}$ & N.A \\
\hline $\mathrm{COD}$ & $\begin{array}{c}\text { Filtering } 1.6 \mu \mathrm{m}+ \\
1<\mathrm{pH}<2 \text { with } \mathrm{H}_{2} \mathrm{SO}_{4}\end{array}$ & Filtering $1.6 \mu \mathrm{m}+$ cool \\
\hline Cations & $\begin{array}{c}\text { Filtration } 0.45 \mu \mathrm{m}+ \\
1<\mathrm{pH}<2 \text { with } \mathrm{HNO}_{3}\end{array}$ & $\begin{array}{c}\text { Filtering } 0.45 \mu \mathrm{m} \text { to a } \\
\text { bottle rinsed with } \mathrm{HNO}_{3}\end{array}$ \\
\hline $\mathrm{NO}_{2}{ }^{-}, \mathrm{NO}_{3}{ }^{-}, \mathrm{NH}_{4}-\mathrm{N}$ & Cool & Filtering $1.6 \mu \mathrm{m}$ \\
\hline
\end{tabular}

TSS: total suspended solids, $\mathrm{CO}_{3}{ }^{2-}$ : carbonate, $\mathrm{HCO}_{3}{ }^{2-}$ : bicarbonate, TOC: total organic carbon, TIC: total inorganic carbon, TC: total carbon, DOC: dissolved organic carbon, COD: chemical oxygen demand, $\mathrm{NO}_{2}^{-}$: nitrite, $\mathrm{NO}_{3}^{-}$: nitrate, $\mathrm{NH}_{4}-\mathrm{N}$ : ammonium nitrogen.

For microbiological studies, $3 \times 500 \mathrm{~mL}$ process water from Mine 1 location $\mathrm{Z} 4$ was collected by filtration on Sterivex ${ }^{\mathrm{TM}}$ filter units (Merck, Burlington, MA, USA) and frozen on-site at $-20^{\circ} \mathrm{C}$. Additionally, samples were collected as such in $250 \mathrm{~mL}$ sterile plastic bottles (Nunc, Thermo Fisher) and frozen on-site at $-20{ }^{\circ} \mathrm{C}$. The samples were transported on dry ice to the laboratory at VTT in southern Finland. Samples from location 15 of Mine 2 were collected directly into $1000 \mathrm{~mL}$ sterile plastic bottles (Nunc, Thermo Fisher Scientific, Waltham, MA, USA) and frozen on-site at $-20{ }^{\circ} \mathrm{C}$ and transported and kept frozen before analysis at VTT.

\subsection{Investigation of the Effect of Water Matrix on the Analysis Results}

A 1.5 L sample of process water from Mine 2 and synthetic water (denoted as PW and SW, respectively) were collected/prepared on-site. The initial composition of the process water and synthetic control sample (i.e., the baseline samples) is shown in Table 3. The bulk sample was divided into three portions of $500 \mathrm{~mL}$ each, and the $500 \mathrm{~mL}$ samples were labeled as Fraction 1, Fraction 2, and Fraction 3. Fraction 1 represented the baseline sample. Fraction 2 was spiked with $150 \mathrm{mg}$ of $\mathrm{Na}_{2} \mathrm{~S}_{2} \mathrm{O}_{3}$ and $72 \mathrm{mg}$ of $\mathrm{Na}_{2} \mathrm{~S}_{2} \mathrm{O}_{4}$. Fraction 3 was spiked with the same amount of thiocompounds as Fraction 2 and an additional $20 \mu \mathrm{L}$ volume of a solution consisting of $10 \mathrm{mg} / \mathrm{L} \mathrm{CuSO}, 100 \mathrm{mg} / \mathrm{L}$ $\mathrm{Ni}\left(\mathrm{NO}_{3}\right)_{2}$, and $100 \mathrm{mg} / \mathrm{L} \mathrm{FeSO}{ }_{4}$ resulting in final concentrations of $0.4 \mu \mathrm{g} / \mathrm{L}, 4 \mu \mathrm{g} / \mathrm{L}$ and $4 \mu \mathrm{g} / \mathrm{L}$, respectively. All the samples were preserved in the same way, by vacuum filtration using $0.45 \mu \mathrm{m}$ pore size, glass microfiber filters, and fast freezing the sample bottle in a mixture of acetone and dry ice before sending to the laboratory contracted by Mine 2 for analysis.

Table 3. Composition of the process water and the synthetic water that was used as the control sample.

\begin{tabular}{|c|c|c|c|c|c|c|c|c|c|c|c|}
\hline \multirow{2}{*}{ Water type } & $\mathrm{K}^{+}$ & $\mathrm{Ca}^{2+}$ & $\mathrm{Mg}^{2+}$ & $\mathrm{Na}^{+}$ & Tot S & $\mathbf{P}$ & $\mathrm{Si}$ & $\mathrm{Ni}^{2+}$ & $\mathrm{Cl}^{-}$ & $\mathrm{SO}_{4}{ }^{2-}$ & $\mathrm{S}_{2} \mathrm{O}_{3}{ }^{2-}$ \\
\hline & $\mathrm{mg} / \mathrm{L}$ & $\mathrm{mg} / \mathrm{L}$ & $\mathrm{mg} / \mathrm{L}$ & $\mathrm{mg} / \mathrm{L}$ & $\mathrm{mg} / \mathrm{L}$ & $\mathrm{mg} / \mathrm{L}$ & $\mathrm{mg} / \mathrm{L}$ & $\mathrm{mg} / \mathrm{L}$ & $\mathrm{mg} / \mathrm{L}$ & $\mathrm{mg} / \mathrm{L}$ & $\mathrm{mg} / \mathrm{L}$ \\
\hline PW & 65 & 170 & 94 & 200 & 260 & 0 & 7 & 0 & 480 & 670 & 32 \\
\hline SW & 31 & 168 & 28 & 94 & 119 & - & - & - & 329 & 250 & 63 \\
\hline
\end{tabular}

$\mathrm{K}^{+}$: potassium, $\mathrm{Ca}^{2+}$ : calcium, $\mathrm{Mg}^{2+}$ : magnesium, $\mathrm{Na}^{+}$: sodium, Tot $\mathrm{S}$ : total sulfur, $\mathrm{P}$ : phosphorus, $\mathrm{Si}$ : silicon, $\mathrm{Ni}^{2+}$ : nickel, $\mathrm{Cl}^{-}$: chloride, $\mathrm{SO}_{4}{ }^{2-}$ : sulfate, $\mathrm{S}_{2} \mathrm{O}_{3}{ }^{2-}$ : thiosulfate.

\subsection{Preparation of Control Samples}

In order to evaluate the accuracy of the chemical analysis, control samples were prepared for each mine site during the sampling campaigns. The dry compounds were weighed on an analytical balance beforehand and dissolved in distilled water on-site. Control samples were preserved in the same way as the plant water samples. The theoretical values of the control samples are reported in Table 4 . 
Table 4. Composition of the control samples for Mine 1 and Mine 2.

\begin{tabular}{|c|c|c|c|c|c|c|c|c|c|c|c|c|}
\hline Mine & Unity (mg/L) & TDS & $\mathrm{Ca}^{2+}$ & $\mathrm{Cl}^{-}$ & $\mathrm{SO}_{4}^{2-}$ & $\mathrm{K}^{+}$ & $\mathrm{Mg}^{2+}$ & $\mathrm{Na}^{+}$ & $\mathrm{S}_{2} \mathrm{O}_{3}{ }^{2-}$ & $\mathrm{SO}_{3}{ }^{2-}$ & $\mathrm{S}_{4} \mathrm{O}_{6}{ }^{2-}$ & Total S \\
\hline Mine 1 & & 6319 & 661 & 535 & 2570 & 31 & 50 & 1106 & 351 & 275 & 616 & 1553 \\
\hline \multirow{3}{*}{ Mine 2} & S1 & 711 & 59 & 248 & 217 & 37 & 38 & 104 & 7 & 0 & 0 & 76 \\
\hline & S2 & 730 & 61 & 255 & 221 & 38 & 39 & 107 & 8 & 0 & 0 & 74 \\
\hline & S3 & 966 & 61 & 254 & 220 & 37 & 39 & 168 & 8 & 54 & 69 & 157 \\
\hline
\end{tabular}

One control sample prepared for Mine 1 was sent for analysis during the sampling campaign. Three control samples were prepared for Mine 2. The first sample (S1) was sent together with samples from the plant (28 samples), during the winter sampling campaign. The second (S2) and third (S3) control samples were prepared and sent for analysis a month later. S1 and S2 have similar compositions, while S3 contained 16 times more reduced sulfur compounds added as tetrathionate $\left(\mathrm{S}_{4} \mathrm{O}_{6}{ }^{2-}\right)$ and sulfite $\left(\mathrm{SO}_{3}{ }^{2-}\right)$ compared to $\mathrm{S} 1$ and $\mathrm{S} 2$, as presented in Table 4.

\subsection{Kinetics of Degradation of Water during the Sample Preparation Procedure}

Since the samples were kept in the laboratory after the collection for some time before being prepared and stabilized due to the limited number of personnel, a degradation test was set up to evaluate the kinetics of degradation. The flotation feed slurry of plant 1 from Mine 1 was used for this study. A $10 \mathrm{~L}$ slurry sample was taken in a bucket. Right after the collection, sulfate was analyzed with the sulfate cuvette test kit LCK353 (Hach Lange, Düsseldorf, Germany) with a Hach spectrophotometer (Hach Lange, Düsseldorf, Germany) and the concentration of DO was measured with a YSI ProDSS multiparameter probe (YSI, Xylem Inc., Yellow Springs, OH, USA). The sulfate analysis was performed with $0.45 \mu \mathrm{m}$ filtrated, diluted samples in triplicate. The DO measurements were performed directly in the bucket whilst the pulp was gently stirred. Every $2 \mathrm{~h}$ the DO and sulfate concentration were checked/analyzed. The bucket was closed with a lid between the analysis. The degradation test lasted for $10 \mathrm{~h}$. During this period, the temperature of the slurry was maintained constant and close to the initial temperature by storage in an air conditioned storage room (around $20^{\circ} \mathrm{C}$ ). Therefore, the variation (if there was any) of the DO and sulfate were assumed to be due to the various ongoing reactions in the slurry.

\subsection{Extraction of Microbial Cells and DNA from Samples Z4 (Mine 1) and 15 (Mine 2)}

The content of microbial cells in the two samples, Z4 (Mine 1) and 15 (Mine 2), was examined by microscopy. The samples were analyzed as such by staining with 4'6-diamidino-2-phenylindole (DAPI) (Sigma-Ardrich D9542, Merck, Burlington, MA) and visualized under UV light using a Zeiss Axio Imager M2 epifluorescence microscope (Carl Zeiss Microscopy, Göttingen, Germany) with 100 $\times$ magnification (Appendix A, Table A5; Direct microscopy). In addition, several procedures were tested for microbial cell detachment and enumeration (Appendix A, Table A5). The extraction of microbial DNA from the samples was tested using four commercial kits designed for demanding soil samples (Appendix A, Table A6). The efficiency of the commercial kits was examined by adding an amount of bacteria (liquid culture of Desulfovibrio desulfuricans) to the samples, allowing for the bacterial cells to attach to the mineral solids of the samples, and then performing DNA extraction according to the manufacturer's instructions. As reference, DNA was extracted from duplicate $10 \mathrm{~mL}$ samples of $D$. sulfuricans culture, triplicate Sterivex ${ }^{\mathrm{TM}}$ (Merck, Burlington, MA, USA) (of $500 \mathrm{~mL}$ sample water filtered) filters of Mine 1 sample Z4 and triplicate $5 \mathrm{~mL}$ samples of Mine 2 sample 15 using the Macherey-Nagel Soil DNA extraction kit (Macherey-Nagel GmbH \& Co, KG, Düren, Germany) with lysis buffer 1 and SX solution (Appendix A, Table A6). The amount of isolated DNA was measured using the Qbit fluorometer (Fisher Scientific, Loughborough, UK). 


\section{Results}

\subsection{Physicochemical Property Measurement}

Physicochemical measurement was one of the major challenges encountered during the evaluation, even though the measurements followed the recommendations from the published literature $[7,18,20]$. These studies indicated that the measurements should be done in the laboratory while stirring the slurry slowly and the reading should be done only when the probe indicates a stabilized value (generally over two minutes), which signifies an equilibrium between the probe and the media. However, in reality, this practice might not be applicable due to the high reactivity of the slurry that changes the reading over a very short period of time. This observation is presented in Figure 1, which shows the measurements of ORP, DO, pH, and SPC taken in three locations of Mine 1. It should be noted that the measurements were performed in all locations from which samples were sent for chemical analysis. However, due to the large amount of data, only three measurements at three critical locations (output of grinding, feed to flotation and tailings) of Mine 1, plant 1 are presented in order to clarify these observations. The measurements were recorded for $10 \mathrm{~min}$. They showed that $\mathrm{pH}$ tended to slightly decrease over time. However, the level of attenuation was not significant. The value of SPC was mostly constant during the measurement, and only small variations were observed. In contrast, the variations of DO and ORP were strong. The DO level decreased significantly during the two first minutes and reached a value of zero after $4 \mathrm{~min}$. As the variation of DO and ORP followed the same trend, the same decreasing tendency was observed for ORP. The ORP value dropped from a near-zero value to a very negative value after 3 min of reading (location 3 ) and the DO dropped to a value close to zero after 2 min of measurement.
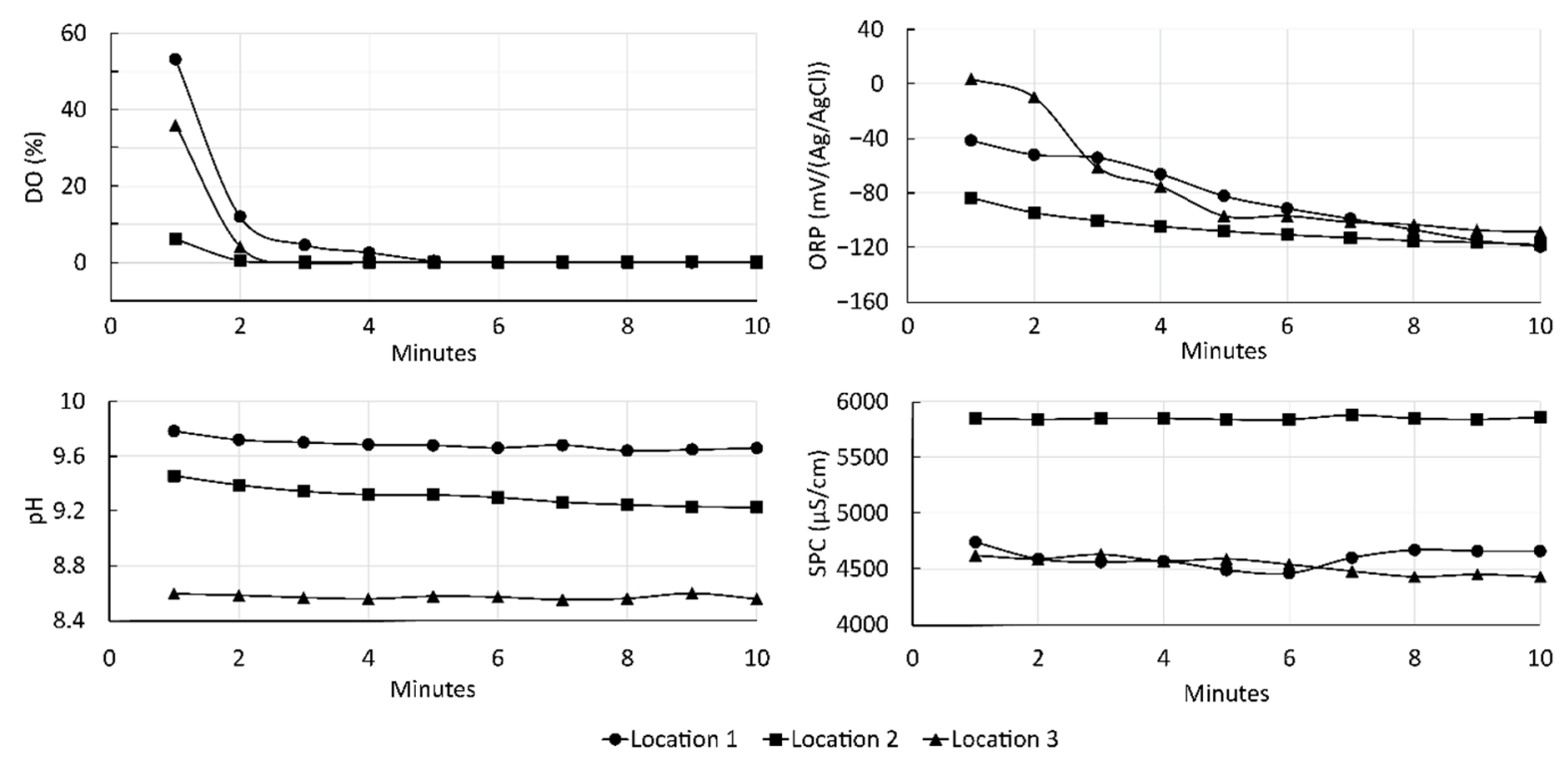

Figure 1. Variation of physicochemical readings as a function of the reading time.

\subsection{Chemical Composition Assessment}

\subsubsection{The Reproducibility of the Analysis}

The analysis was done in triplicate for several locations in the processing plant water circuit to investigate the reproducibility of the analysis for both mines. The relative standard errors calculated from the triplicate samples of Mine 1 are presented in Figure 2. Overall, the results showed good reproducibility for TDS, $\mathrm{pH}$, magnesium, calcium, potassium, sodium, total sulfur, sulfate, tetrathionate, and thiosulfate. The relative standard errors for these compounds/elements were less than $20 \%$. However, the high relative standard errors (i.e., unsatisfactory reproducibility of the analysis) was 
observed for chloride, zinc, and sulfite, particularly for the samples from Mine 1 . The relative standard error of chloride, zinc, and sulfite at plant 1 location 2 were $50 \%, 53 \%$, and $88 \%$, respectively. Meanwhile, the relative standard error of other elements of the same sample remained lower than $10 \%$. Such a phenomenon was not observed for Mine 2 where the triplicate samples' relative standard errors were less than $15 \%$ for all variables, which means a satisfactory reproducibility of the analysis.

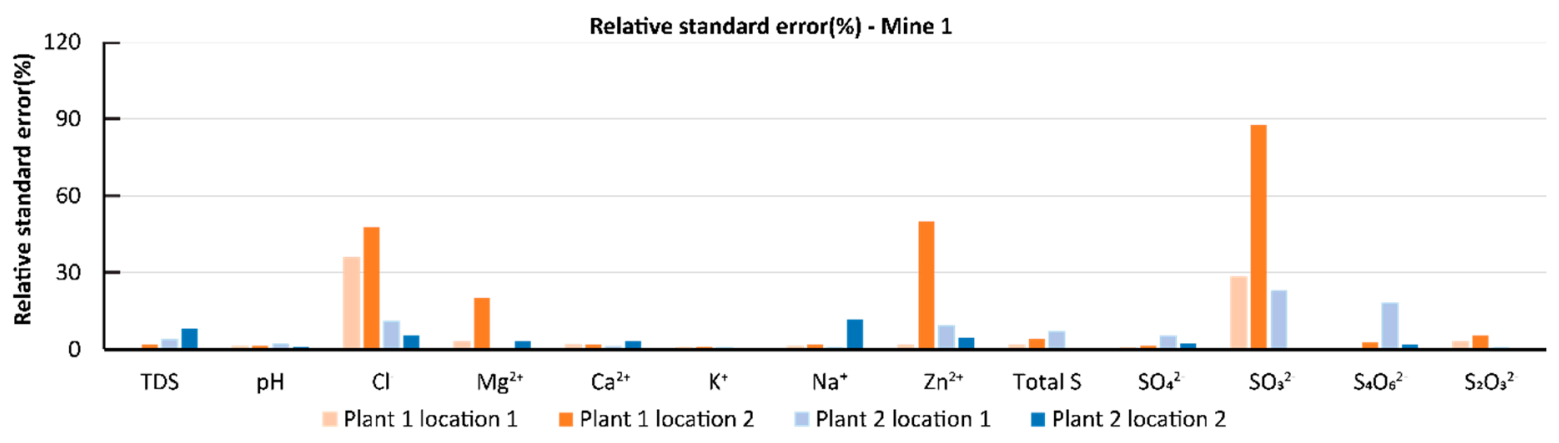

Figure 2. Relative standard error of different compounds of samples taken in the two plants of Mine 1.

\subsubsection{Analysis Quality of the Control Samples}

The difference between the theoretical value and the analysis results from the laboratory were reported in percentages and are shown in Table 5. The percentage difference in the results was calculated by dividing the absolute difference between the theoretical value and the laboratory value by the theoretical value.

Table 5. Theoretical values and analysis results of the control samples (the analysis where the difference is significant is highlighted in red).

\begin{tabular}{|c|c|c|c|c|c|c|c|c|c|c|c|c|}
\hline \multirow{3}{*}{ Parameters } & \multicolumn{3}{|c|}{ Mine 1} & \multicolumn{9}{|c|}{ Mine 2} \\
\hline & \multicolumn{3}{|c|}{ S1 } & \multicolumn{3}{|c|}{ S1 } & \multicolumn{3}{|c|}{ S2 } & \multicolumn{3}{|c|}{ S3 } \\
\hline & TV & LV & Diff. & TV & LV & Diff. & TV & LV & Diff. & TV & LV & Diff. \\
\hline Unity & $\mathrm{mg} / \mathrm{L}$ & $\mathrm{mg} / \mathrm{L}$ & $\%$ & $\mathrm{mg} / \mathrm{L}$ & $\mathrm{mg} / \mathrm{L}$ & $\%$ & $\mathrm{mg} / \mathrm{L}$ & $\mathrm{mg} / \mathrm{L}$ & $\%$ & $\mathrm{mg} / \mathrm{L}$ & $\mathrm{mg} / \mathrm{L}$ & $\%$ \\
\hline TDS & 6319 & 5517 & 13 & 711 & 1900 & 167 & 730 & 790 & 8 & 966 & 1000 & 3 \\
\hline $\mathrm{Ca}^{2+}$ & 661 & 655 & 1 & 59 & 46 & 23 & 61 & 52 & 15 & 61 & 52 & 15 \\
\hline $\mathrm{Cl}^{-}$ & 535 & 1452 & 172 & 248 & 230 & 7 & 255 & 230 & 10 & 254 & 240 & 5 \\
\hline $\mathrm{SO}_{4}^{2-}$ & 2570 & 2827 & 10 & 217 & 250 & 15 & 221 & 210 & 5 & 220 & 280 & 27 \\
\hline $\mathrm{K}^{+}$ & 31 & 34 & 10 & 37 & 32 & 13 & 38 & 35 & 7 & 37 & 35 & 6 \\
\hline $\mathrm{Mg}^{2+}$ & 50 & 54 & 9 & 38 & 33 & 14 & 39 & 32 & 18 & 39 & 33 & 15 \\
\hline $\mathrm{Na}^{+}$ & 1106 & 1184 & 7 & 104 & 97 & 7 & 107 & 97 & 9 & 168 & 160 & 5 \\
\hline $\mathrm{S}_{2} \mathrm{O}_{3}{ }^{2-}$ & 351 & 681 & 94 & 7 & 14 & 89 & 8 & 7 & 15 & 8 & 44 & 452 \\
\hline $\mathrm{SO}_{3}^{2-}$ & 275 & 1 & 100 & 0 & n.a & & 0 & n.a & & 54 & n.a & \\
\hline $\mathrm{S}_{4} \mathrm{O}_{6}{ }^{2-}$ & 616 & 767 & 24 & 0 & n.a & & 0 & n.a & & 69 & n.a & \\
\hline Total S & 1553 & 1435 & 8 & 76 & 89 & 16 & 74 & 70 & 5 & 157 & 160 & 2 \\
\hline
\end{tabular}

TV: theoretical value, LV: laboratory value, Background color: Value is higher than $20 \%$.

For Mine 1, the overall results showed a low error of analysis for all compounds/elements, except chloride, thiosulfate, and sulfite. The difference between the theoretical value and the laboratory value for chloride, thiosulfate, sulfite, and tetrathionate was 172\%, 94\%, 100\%, and 24\%, respectively.

For Mine 2, the first control sample revealed a high error in terms of TDS, calcium, and thiosulfate, while the second control sample, which had a similar composition, showed a low error of analysis for all compounds/elements. All errors were lower than $20 \%$ for the second control sample. This result suggested that the laboratory likely had difficulties in handling the large number of samples simultaneously during the sampling campaign. Another explanation could be that there was sample contamination. The third sample showed a higher error in the sulfate and thiosulfate analysis in comparison to the values observed in the second control. The only difference between the second 
and third control sample was that the third sample contained a spiked amount of tetrathionate and sulfite in its water matrix. This result suggested that the presence of a high amount of reduced sulfur compounds influenced the analysis of sulfate and thiosulfate. It is also important to notice that the laboratory chosen to analyze the samples from Mine 2 was not able to analyze other thiosalt species. Therefore, data concerning the uncertainty of these speciation compounds are unavailable.

\subsubsection{Balance of TDS and Sulfur}

In order to evaluate the quality of the analysis, we calculated the balance of TDS measured vs. the sum of major compounds and total $S$ measured vs. S calculated from $S$ compounds. The difference between two values in percentage is defined as the quotient between the difference and the mean value. Theoretically, the balance should be close to zero.

The comparison between the TDS measured and the sum of major compounds for Mine 1 and Mine 2 is illustrated in Figure 3. The results show that for both mines, the sum of major elements is generally higher than the TDS measured. The $t$-test results for comparing TDS and the sum of major compounds are provided in Appendix A, Table A2. The low value of $p(<0.01)$ for the one-tailed test indicates that the null hypothesis can be rejected, and the quantities differ in a particular direction. For Mine 1, the imbalance was generally around 30\%. However, it could be more than 50\% in several locations. For Mine 2, different behavior of the imbalance in summer and winter was observed. In winter, the difference between TDS measured and the sum of major compounds was quite constant, with an average value of around 15\%. Meanwhile, during summertime, that imbalance fluctuated more. The difference between TDS measured and the sum of major compounds was particularly large for samples coming from the processing plants (location 10 to location 18), the output of the high sulfur tailings dam (location 6), and the Ni circuit tailings (location 23). Other locations, which were mostly from the mine outside the water circuit, exhibited low imbalance.

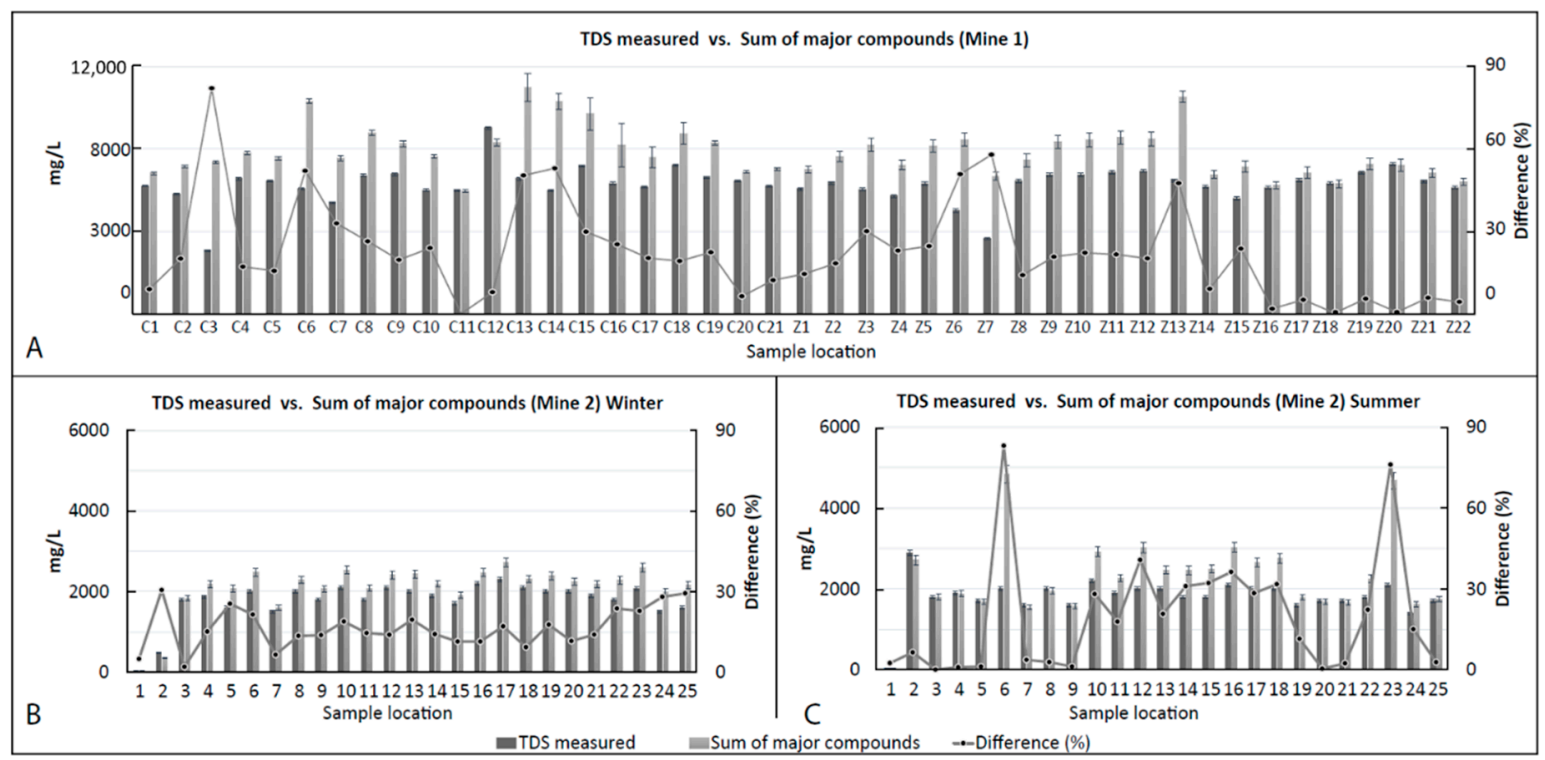

Figure 3. Balance of TDS calculated for samples from Mine 1 (A) and Mine 2 winter survey (B) and summer survey $(\mathbf{C})$.

Figure 4 shows the sulfur balance of Mine 1 and Mine 2. The $t$-test results for comparing total S and $\mathrm{S}$ calculated from $\mathrm{S}$ compounds are provided in the Appendix A, Table A3. The low value of $p$ $(<0.01)$ for the one-tailed test indicates that the null hypothesis can be rejected. The results indicate a high imbalance especially for several samples from Mine 1 (location C13 to C18). The differences between total sulfur measured and total sulfur calculated from compounds for those locations were higher than $30 \%$ and could reach more than $70 \%$. The imbalance of sulfur was more significant for 
Mine 2 than Mine 1. Moreover, the imbalance of sulfur in summertime was more significant than in the wintertime.

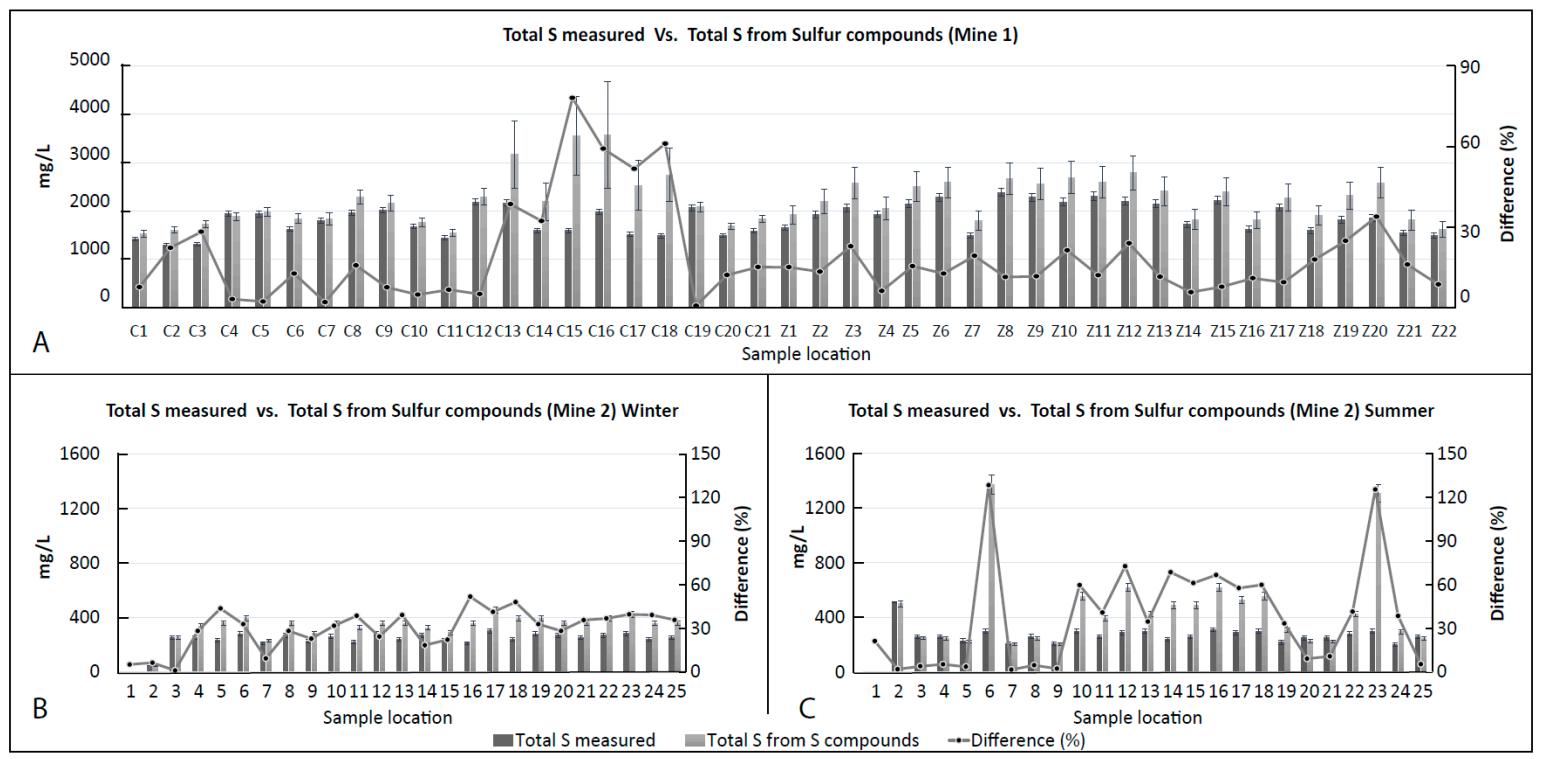

Figure 4. Balance of sulfur calculated for samples from Mine 1 (A) and Mine 2 winter survey (B) and summer survey $(\mathbf{C})$.

The imbalance of total sulfur compounds and TDS suggested an analytic problem. A positive imbalance toward the sum of major compounds suggested an overestimation of at least one of the major elements. For Mine 1, the control samples suggested that chloride and tetrathionate were overestimated. For Mine 2, due to the similar curve shape between the imbalance of TDS and total sulfur compounds in summertime, the overestimation of one of those sulfur compounds could be the reason for the imbalance in TDS. This explanation corroborated with the results observed in the control sample. The high temperature in Mine 1 during summertime increased the amount of reduced sulfur compounds such as tetrathionate and sulfite in the process water. Therefore, the concentrations of sulfate and thiosulfate could be overestimated due to the matrix effects.

\subsubsection{Effect of the Water Matrix on the Analysis Results}

As presented in Section 3.2.2, the addition of thiosalt compounds seemed to affect the analysis quality of the control sample. Therefore, this section is dedicated to a study of the potential effect of the water matrix on the analysis results. The differences between the analyses of spiked waters and the theoretical values are shown in Figure 5. An interesting observation presented in the table is related to the strong influence the initial water matrix had on the chemical analysis results. The addition of thiocompounds to the SW matrix altered the analysis of potassium, magnesium, total sulfur, and chloride, whilst the addition of the same compounds in the process water did not have any notable effect. The interference of thiocompounds in the SW matrix created an overestimation of these compounds. However, the addition of metals seemed to attenuate the interference of thiosalt in the SW matrix. The difference was generally reduced by half.

Inversely, the addition of metals reinforced the interference of thiosalt in the PW matrix. The difference then increased up to $40 \%$. These values were higher than the standard errors of the analysis reported from the samples from the sampling campaigns and were generally from 10-15\%. 

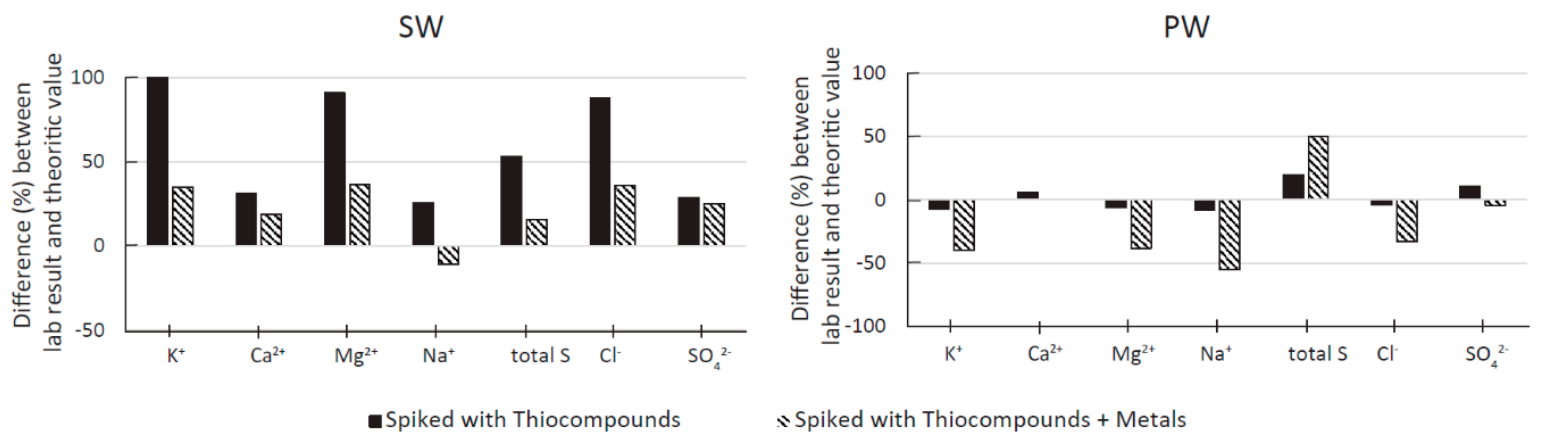

Figure 5. The difference (expressed in \%) between the analysis of spiked waters and non-spiked water.

\subsubsection{Sample Degradation}

In addition to the in situ analysis, $\mathrm{pH}$ was also measured in the laboratory to investigate the degradation state of the water. Any major changes in $\mathrm{pH}$ indicated a modification of the water matrix. Figure 6 shows that the $\mathrm{pH}$ measured in the laboratory was consistantly lower than the in situ measurements, with a difference around four or five units. The $t$-test results for comparing means of the $\mathrm{pH}$ of each pair of observations (laboratory vs. in situ) are provided in Appendix A, Table A4. The low value of $p(<0.01)$ for the one-tailed test indicates that the null hypothesis can be rejected, and the quantities differ in a particular direction. In some locations, the differences were higher than $60 \%$. On average, the difference was $45 \%$. Additionally, it is worth noting that since the $\mathrm{pH}$ scale is the base 10 logarithm of free acidity, the magnitude of difference in terms of free acidity was from $10^{4}$ to $10^{5}$.

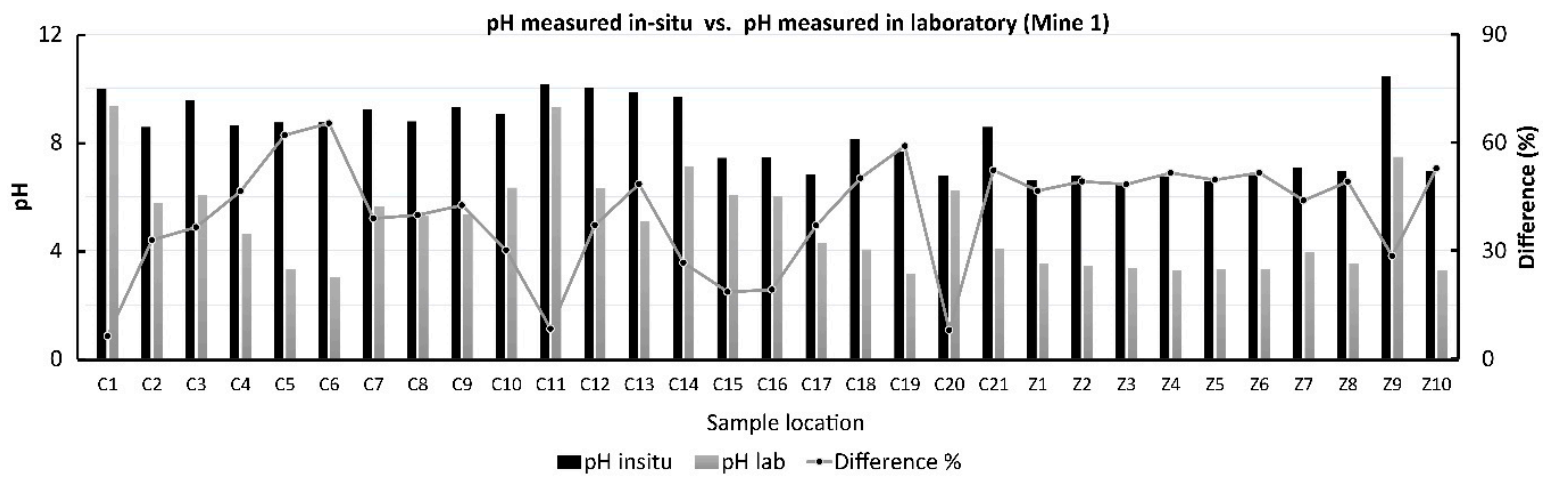

Figure 6. The $\mathrm{pH}$ measured in the laboratory vs. $\mathrm{pH}$ measured in situ.

\subsection{Microorganisms}

The number of microbial cells in the Mine 1 Z4 and Mine 215 samples exceeded $1.6 \times 10^{8}$ microbial cells per $\mathrm{mL}$ sample when examined by microscopy, but an exact number was impossible to determine, due to the amount of solid particles in the sample that hid part of the cells (Figure 7, Appendix A, Table A5). To be able to count or further characterize the microorganisms they need to be detached from the particles they are bound to. By using $4 \mathrm{~mL} 0.9 \% \mathrm{NaCl}$ solution or Milli-Q water for a $1 \mathrm{~mL}$ sample, the proportion of detached cells was only approximately $0.1 \%$ of the cell amount estimated by microscopy. The same result was achieved by ultrasonication using $4 \mathrm{~mL} 0.9 \%$ $\mathrm{NaCl}$ or Milli-Q water with or without detergent as detachment solution. Tween $20(0.4 \% \mathrm{v} / \mathrm{v})$ in $4 \mathrm{~mL}$ $0.9 \% \mathrm{NaCl}$ solution or Milli-Q water detached approximately $1 \%$ of the microbial cells, whereas $0.04 \%$ $(w / v)$ Zwittergent 3-12 in Milli-Q water detached only $0.1 \%$ of the cells. An increase in the volume of extraction solution somewhat affected the number of detached cells, with both Tween $20(0.4 \%)$ and Zwittergent 3-12 (0.04\%) in $29 \mathrm{~mL}$ Milli-Q water extracting approximately 2-20 times more cells than the smaller volumes did. Serial extraction with a first round of $349 \mathrm{~mL}$ Milli-Q water followed by a second round with $150 \mathrm{~mL}$ Milli-Q water extracted $4.6 \%$ and $3.3 \%$ of the cells in the Mine 1 and Mine 2 
samples, respectively. The same procedure repeated with Milli-Q water containing 0.4\% Tween 20 was able to extract approximately $3.3 \%$ of the estimated number of cells detected in the Mine 1 sample, and up to $11.3 \%$ of the cells in the Mine 2 sample.
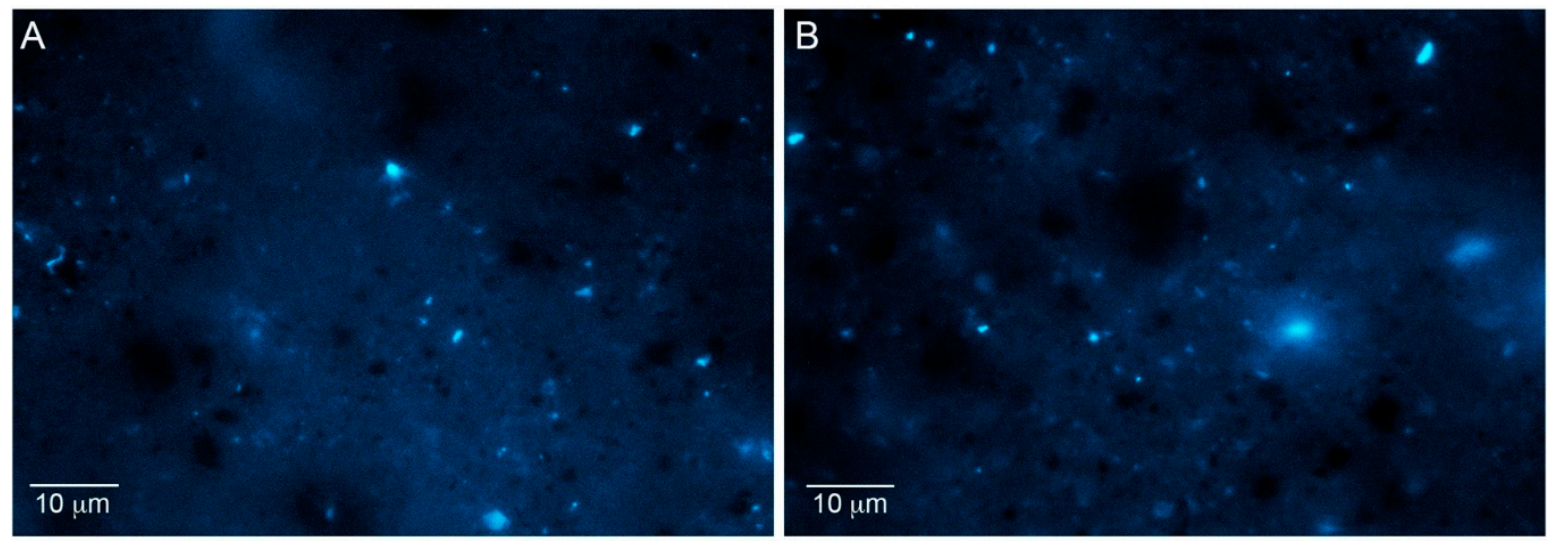

Figure 7. Epifluorescence microscopy images of (A) Mine 1 sample Z4 and (B) Mine 2 sample 15. The microbial cells have been dyed with DAPI and show as bright blue under UV light. The dark areas of the images are particles from the sample. The scale bar in the lower left corner of each image represents $10 \mu \mathrm{m}$.

The amount of microbial DNA obtained from the original samples was below the limit of detection of the assay, the limit being $0.025 \mathrm{ng}$ of DNA/5 mL sample (Appendix A, Table A6). The amount of DNA extracted from two $10 \mathrm{~mL}$ samples of $D$. desulfuricans culture was approximately $180 \mathrm{ng} / \mathrm{mL}$ from each sample. Using the Macherey-Nagel Soil DNA extraction kit, lysis buffer 1 and enhancer solution SX, approximately $0.6-7 \%$ of the added $D$. desulfuricans DNA could be retrieved from Mine 1 sample Z4, while the DNA amount retrieved from Mine 2 sample 15 was below the detection limit. No DNA was detected when using the same DNA extraction kit but lysis buffer 2. The PowerMax Soil DNA extraction kit (MoBio Laboratories, Inc, Carlsbad, CA, USA) extracted less than 0.01\% of the added DNA from each sample, whereas the ZR SoilMicrobe DNA Midiprep (Zymo Research Corp. n.d., Irvine, CA, USA) kit extracted $0.1 \%$ of the added DNA. The NucleoBond ${ }^{\circledR}$ RNA soil (Macherey-Nagel GmbH \& Co, KG, Düren, Germany) + DNA Kit (Macherey-Nagel GmbH \& Co, KG, Düren, Germany)did not extract any DNA from Mine 1 sample Z4, but extracted approximately $0.2 \%$ of the added $D$. desulfuricans culture DNA from the Mine 2 sample 15.

\section{Discussion}

\subsection{Potential Causes for the Poor Results of the Water Analysis}

In terms of physicochemical assessment, the dropping of DO and ORP during the measurements raised an important question: What value should be considered as the value of the DO and ORP? Should we wait until an equilibrium is obtained? The likely answer to the posed question is: No. There is no sense to wait until an equilibrium is attained but reading right after the introduction of the sensor into the slurry is equally not a good decision. Theoretically, the variation of physicochemical parameters during the measurement was attributed to two main reasons: The ongoing reaction in the slurry or the stabilization of the electrode. In this case, the strong decrease in DO suggested that a reaction which consumed oxygen was ongoing, as the oxygen was one of the most important oxidizers in the slurry, and the ORP decreased over time, which has also been observed in earlier studies [20]. Due to the nature of the water matrix and the ore mineralogy, the major causes of oxygen consumption might be the oxidation reactions of reduced sulfur compounds to sulfate, interactions between liquid and solid phases, and bacterial activities. 
Consequently, we now face difficulties in deciding the correct values for ORP and DO readings due to the oxido-reduction reactions in the slurry. To collate more reliable readings, several options could have been considered. These options include: (1) Reading the value after the same length of insertion of the probe into the slurry (e.g., one minute of insertion of the probe into the slurry) or (2) installing the probe directly in the stream. It should be noted that the sampling method employed in this study was spot (bottle) sampling, which entailed collecting a single sample at a given time and location in the process. The information obtained from this technique was unique to the sampling place and time selected. Hence, it seemed obvious that such an approach could not give a representative picture of the water variation quality over time. In practice, due to the distinct spatial or temporal correlation along the main direction of the flow, the most appropriate method for sampling such water streams is composite or aggregate sampling [15,21].

In terms of chemical analysis, several potential causes for the unreliable results could be pointed out. Firstly, minimal emphasis was placed on the preservation method. It should be borne in mind that the initial sample must be preserved in a way that maintains constant water properties until the time of analysis. Failure to correctly preserve the water renders the readings/analysis results meaningless. The change in $\mathrm{pH}$, which is a major physicochemical property of the sample, indicated that the preservation of the sample at $4{ }^{\circ} \mathrm{C}$, as suggested by the certified laboratory, is not sufficient or adequate to prevent the degradation of the water. The literature has indicated that the oxidation of thiosalts into a higher state of oxidation acidifies the media [22,23]. The significant drop in $\mathrm{pH}$, in this case, agreed with the literature. Moreover, different studies have focused on thiosalt compounds and concluded that $\mathrm{pH}$ plays a crucial role in the stability and speciation of thiosalt compounds [24]. Thiosulfate is unstable under $\mathrm{pH} 4$, while tetrathionate is unstable at a $\mathrm{pH}$ higher than 9. Studies by the same authors also showed that the decomposition of thiosalts continued even at low temperatures. However, the literature on the preservation of mining effluent water placed less emphasis on the preservation of sulfur compounds. The report titled, "Guidance Document for the Sampling and Analysis of Metal Mining Effluent: Final Report" [7] even suggested that samples meant for sulfate analysis can be preserved for up to 28 days without any specific condition of preservation. Such a suggestion might not be applicable for mining process waters which contain thiosalts and many studies have pointed out that the oxidation of thiosalt compounds can have sulfate as the final product $[22,24,25]$. The literature also indicated that minimal effort was assigned to thiosalt preservation and analysis because of its low toxicity to animals. Thiosalts are not expected to be dangerous compounds that must be monitored in mining effluents [2]. However, thiosalts can have a great impact on flotation performance [26,27]. These adverse impacts on flotation confirm the suggestion that the monitoring program for mining effluent waters is not suitable for monitoring process water.

Secondly, if the unsatisfactory reproducibility of the analysis was derived from variation of water quality, the high relative standard error should be observed in all elements/compounds and not only in specific elements/compounds, as in our case. This observation may support the hypothesis that it was more likely a problem of delivering consistent analysis results from the analysis laboratory than a problem of high variations in water quality. Therefore, it is appropriate to suggest that the analysis laboratories revise their sample handling procedures.

Thirdly, the waiting time between sampling and sample preparation can be a factor that impacts the analysis results. In practice, all samples were generally collected together in the morning and then transferred to the laboratory for preparation. Due to the high number of samples and the limited number of personnel, the samples were kept in the laboratory for some time before being prepared and stabilized. Figure 8 shows the variation of DO (in \%) and sulfate as a function of the waiting time. The level of DO gradually decreased over time, from $75 \%$ to $35 \%$ after $10 \mathrm{~h}$. The concentration of sulfate ions decreased significantly after two hours of waiting, increasing again after six hours. The mechanism of this phenomenon remained unclear but, owing to the variations of a major physicochemical parameter such as DO, the sulfur species clearly changed. Nevertheless, microbial oxidation of sulfur species may also occur. 


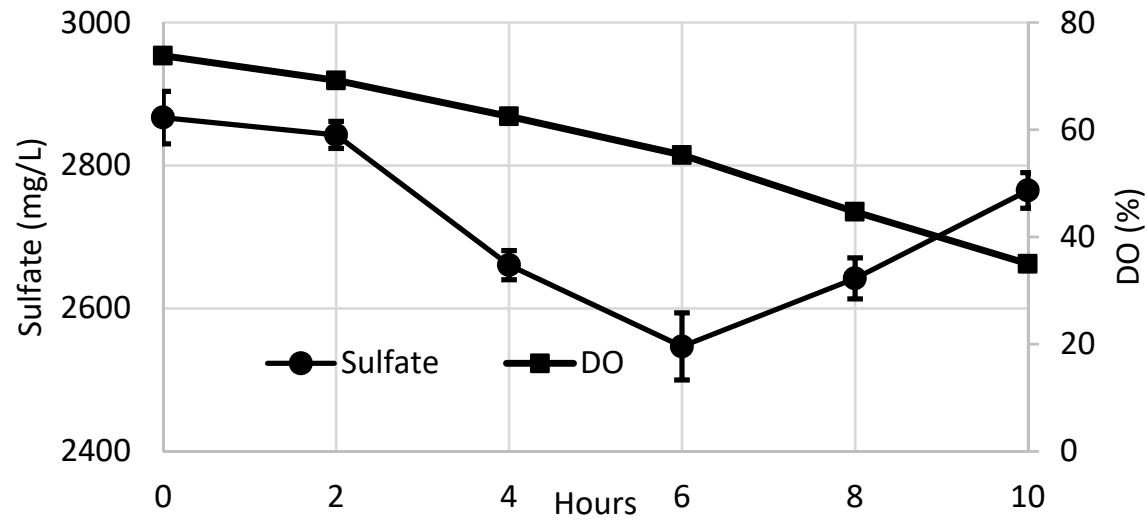

Figure 8. Variation of dissolved oxygen (DO) (in \%) and sulfate of a slurry sample as a function of time.

Finally, the errors could also stem from the laboratory analysis procedure. The exceptionally high concentration of chloride ions observed in Mine 1 is an example. The laboratory attributed the overestimation of chlorides to interference of analysis by the thiosalts present in solution. The laboratory suggested a change in technique, opting to employ ionic chromatography for other samples that were sent later. However, the problem still persisted. Similarly, the laboratory's inability to analyze all the required thiosalt speciations could also stem from the inappropriately chosen analysis method, in addition to other possibilities, such as (1) the analysis method was not suitable to analyze such complicated water matrices or (2) the water sample degraded before the actual analysis.

\subsection{Importance of Microorganisms}

Microorganisms live naturally in mining environments and attach strongly to mineral surfaces. The extent of microbial colonization of the process water samples studied here was surprisingly high (Figure 7, Appendix A, Table A5), which may affect the quality of the water as well as have effects on sample preservation. Our tests showed that microorganisms may be extremely difficult to measure, but they are highly abundant. In addition, the methods used for extracting microbial cells and nucleic acids from mining and process water samples greatly affect the outcome of the study. The microorganisms (or their DNA) that are retained on the surfaces of the solids will most likely be neglected.

Appropriate preservation of the samples and the waiting time before analyses are the two most significant factors that can also affect the samples from the microbiological point of view. It has been shown that microbial activity in some sulfide flotation circuits may be very high and induce major changes in $\mathrm{pH}$ and ORP in rather short periods of time [13]. Other process types have also been shown to be affected by the microorganisms, i.e., apatite flotation process selectivity suffered due to the presence of microorganisms [28]. Information on the importance and effects of the naturally inhabiting and prevailing microorganisms in mineral processing is limited in the scientific literature [18]. However, it is clear that microorganisms are present in mineral processing waters [29]. The microorganisms impact the process water quality, but also affect the stability of the water samples stored before physicochemical analyses, which needs to be considered. Active microorganisms use compounds in the water as an energy source for their growth and multiplication, i.e., biomass production. These processes especially affect the amounts of organic and inorganic carbon, phosphate, nitrogen, and sulfur compounds in mining waters.

A practical approach to manage the microbial activity in sampling is either by decreasing the storage temperature to below $4{ }^{\circ} \mathrm{C}$ if the analysis takes place within one to two days, or to freeze the samples immediately after collection until the analysis can be performed. The addition of chemical compounds can lower the microbial activity but may interfere with the chemical composition of the sample. Chemicals such as peracetic acid, cupric ascorbate, formaldehyde, hydrogen peroxide, guanidium thiocyanate, glutaraldehyde, and sodium hypochlorite are used 
for inactivating microorganisms or lowering their activity [30]. The efficiency of disinfectants depends on the water components, such as particles and organic matter that are considered to protect microorganisms from different disinfectants. If disinfectants are to be used, their efficiency needs to be tested for each water type before use, both due to the sufficient microbial inactivation and the effects on water chemistry. A third possibility is to remove microorganisms (and thus also solids) from the water samples, but that is labor intensive, as microorganisms are small and filters down to $0.2 \mu \mathrm{m}$ or $0.1 \mu \mathrm{m}$ pore size should be used to ensure their removal.

Similarly, as the physicochemical parameters should be followed in mining waters more carefully to better manage the processes, the amounts of microorganisms and their activities should be analyzed. Nevertheless, this is a demanding task and requires fundamental methodology development for these specific environments, which was also demonstrated in this study.

\subsection{Recommendations}

The examples presented in this study clearly demonstrate that the analytical laboratories (even if certified) are not necessarily aware that the complex water matrices and numerous unstable compounds present in mining and minerals processing waters can cause special challenges in terms of sample preservation and analysis. The results showed that sulfur compounds are one of the most challenging in terms of preservation. Several suggestions to overcome the challenge could be found in the literature. However, even despite using these methods, speciation might change while the sample is transported from the site to the laboratory. Therefore, due to their instability, thiosalt analysis should ideally be done on-site [22]. The most commonly determined method for the total concentration of thiosalt compounds that can be conducted on-site is titration [31]. However, if the on-site analysis is not available, samples should be preserved via filtration and fast freezing in liquid nitrogen or in a mixture of acetone-alcohol and be analyzed within 7 days [22]. After fast freezing, samples must be stored frozen and in dark conditions. The thawing process must be done just before the analysis, in a controlled thermostated bath. Additionally, it is worth notifying the laboratory about the required $\mathrm{pH}$ adjustment. Thiosalt analysis standards call for analysis that requires the use of some eluent that might modify the solution $\mathrm{pH}$ [32]. However, it is shown in the literature that the thiosalt speciation changes with $\mathrm{pH}$. It is therefore extremely important that those additions are carefully considered and, if necessary, only to be done right before the analysis $[22,24,25]$. In general, thiosalts are stable at $\mathrm{pH}$ values between 4 to 7 , and extremely unstable under very basic or acidic $\mathrm{pH}$, even though the stability of thiosalt compounds is temperature dependent [22].

Due to the problem of the matrix interference, analysis methods that are usually applied for environmental and drinking water samples will quite likely not be applicable for the analysis of mine process waters. Additionally, mining waters are also mine specific. Therefore, there is probably no standard analysis procedure that fits all the mining waters. This means that the sample preservation and analysis procedure needs to be customized on a case by case basis. Obtaining reliable analysis results is also critical for implementing water treatment and process control measures. The presence of different thiosalt species can negatively affect the froth stability and flotation performance in sulfide ore processing $[26,27,33]$.

It is therefore recommended that before installing regular sampling programs or conducting large one-time sampling surveys, a pre-study and in depth discussions are done in collaboration with the analytical laboratory to identify the presence of compounds/microorganisms that might cause deterioration of the samples between sampling and analysis. After identification, suitable preservation and analysis methods need to be identified and implemented that ensure the accuracy and reproducibility of the obtained data. This approach ensures that the significant amount of financial resources that need to be invested in such campaigns bring reliable results. It is therefore critical that metallurgists, operators, and sampling personnel involved in these campaigns possess a comprehensive understanding of the preservation methods, while the laboratory personnel is aware of the specific analysis requirements for these specific sample types. 


\section{Conclusions}

The present research aimed to investigate the suitability and accuracy of the current sampling and analysis methodology for mining waters. Based on previous studies, this study focused on evaluating water quality for process performance purposes and not only for fulfilling environmental regulations. The water samples considered in this study were effluents discharged from the mine and also plant waters characterized by a high instability.

The results of the study showed that the methodology for the evaluation of mining effluents for environmental purposes is not suitable for evaluating process waters recirculated in the mineral processing plants. The preservation and analysis methods suggested and routinely used by the contracted commercial analytical laboratories were not appropriate for preserving and analyzing the process water and plant slurry samples. The laboratories were not able to assess the correct elemental concentration values for the control samples. The quality of the analysis was unreliable as the balances of sulfur and TDS were not comparable in many samples.

Two major factors that contributed to the low quality of the analysis results have been outlined, i.e., the preservation methodology and the analysis procedure. The preservation suggestion by one of the laboratories failed to preserve unstable compounds, such as thiosalts. The failure to preserve thiosalts was expressed by the drop in $\mathrm{pH}$ measured in the laboratory compared to the in situ measurements. Additionally, the analysis methods practiced in the laboratories were applied to mine discharge water and are not suitable for mineral processing plant water with a complex matrix. As the matrix effect was significant, the analysis procedures must be customized for each mine as the water matrix is mine specific.

This study is significant as it alerts both the mines and the laboratories of the need to review their water analysis procedures regarding inorganic and organic water constituents, as well as to consider the importance of microorganisms. The future of the mining industry, like other industries, will be data driven. For a data-driven mineral processing plant, the operating conditions of the processing plant will be partially or fully decided by an advanced computer analysis program. In such a situation, a good dataset regarding water quality is an essential prerequisite to build the control model and to have meaningful results from the model for process control and optimization.

Author Contributions: Conceptualization, T.M.K.L.; methodology, T.M.K.L., H.M., M.B.; formal analysis, T.M.K.L., H.M., M.B.; investigation, T.M.K.L., H.M., M.B.; writing-original draft preparation, T.M.K.L., H.M., M.B.; writing-review and editing, N.S., H.M., M.B.; visualization, T.M.K.L.; supervision, N.S., O.D.; project administration, N.S., O.D.; funding acquisition, N.S., O.D. All authors have read and agreed to the published version of the manuscript.

Funding: This research received funding from the European Union H2020 program under grant agreement no. 730480, ITERAMS project.

Acknowledgments: The authors would like to acknowledge Mine 1 and Mine 2 for their support, different project partners for their participation in the sampling campaigns, and Ngoni Mhonde for his advice during the writing. Mira Granlund is acknowledged for the microscopy and DNA extraction work.

Conflicts of Interest: The authors declare no conflict of interest.

\section{Appendix A}

Table A1. Methods and standards used by the contracted laboratories for water analysis.

\begin{tabular}{ccc}
\hline \multirow{2}{*}{ Parameter } & \multicolumn{2}{c}{ Method/Standard } \\
\cline { 2 - 3 } & Mine 1 & Mine 2 \\
\hline $\mathrm{pH}, 25^{\circ} \mathrm{C}$ & Potentiometry/EPA method 150.1, SM 4500 H+ B & In situ measurement \\
\hline Conductivity, $25^{\circ} \mathrm{C}$ & Potentiometry/Internal procedure & In situ measurement \\
\hline $\mathrm{TDS}$ & Calculated/SM 2540 G & SFS 3008 \\
\hline
\end{tabular}


Table A1. Cont.

\begin{tabular}{|c|c|c|}
\hline \multirow{2}{*}{ Parameter } & \multicolumn{2}{|c|}{ Method/Standard } \\
\hline & Mine 1 & Mine 2 \\
\hline Tot. Alkalinity & \multirow{3}{*}{ Titration/Norma UNE-EN ISO 9963-1. } & \multirow{3}{*}{ Not applicable (N.A) } \\
\hline Alkal. Carbonates & & \\
\hline Alkal. Bicarbonates & & \\
\hline Thiosulfate & \multirow{3}{*}{ Titration/Internal procedure } & SFS-EN ISO 10304-3 \\
\hline Thiosalts & & \multirow{2}{*}{ N.A } \\
\hline Polythionates & & \\
\hline Sulfate & Gravimetry/Norma UNE-77048. SM 4500 D. & $\begin{array}{l}\text { Int. Method, IC, based on e.g., } \\
\text { SFS-EN ISO 10304-1:2009, IC-EC }\end{array}$ \\
\hline Sulfite & Titration/UNE-EN 77050. SM 4500 B. & \\
\hline Sulfide & Colorimetry/SM $4500 \mathrm{D}$. & \\
\hline DOC & \multirow{2}{*}{ IR Spectrophotometry/SM 5310., UNE-EN 1484.} & \multirow{4}{*}{ SFS-EN 1484} \\
\hline TOC & & \\
\hline TIC & \multirow{2}{*}{ N.A } & \\
\hline TC & & \\
\hline $\mathrm{PO}_{4}^{3-}$ & $\begin{array}{l}\text { Colorimetry (Discrete analyser)/UNE-EN } \\
\text { ISO 6878:2004, Standard Methods 4500-PE }\end{array}$ & SFS 3025 \\
\hline $\mathrm{Cl}^{-}$ & $\begin{array}{c}\text { Colorimetry (Segmented Flow } \\
\text { Analyzer)/Standard Methods } 4500-\mathrm{Cl} \mathrm{E}\end{array}$ & $\begin{array}{l}\text { Int. Method, IC, based on e.g., } \\
\text { SFS-EN ISO 10304-1:2009, IC-EC }\end{array}$ \\
\hline $\mathrm{NH}^{+}$ & $\begin{array}{l}\text { Colorimetry (Discrete analyzer)/Standard } \\
\text { Methods 4500-NH3, UNE-EN ISO11732:1997 }\end{array}$ & SFS 3032, SFS 5505 \\
\hline $\mathrm{NO}^{-}$ & $\begin{array}{c}\text { Colorimetry (Discrete } \\
\text { analyzer)/Standard Methods 4500-NO3 }\end{array}$ & SFS-EN ISO 13395 \\
\hline Nitrite & N.A & SFS-EN ISO 13395 \\
\hline Nitrate-nitrogen & N.A & $\begin{array}{l}\text { Internal Method EF2085, based on } \\
\text { e.g., SFS-EN ISO 11905-1:1998, } \\
\text { Spectrophotometry (CFA) }\end{array}$ \\
\hline Total Nitrogen & N.A & $\begin{array}{l}\text { SFS-EN ISO 11905-2, ISO 15923-1, } \\
\text { Epa Method } 353.1\end{array}$ \\
\hline $\begin{array}{c}\mathrm{Al}, \mathrm{Ca}, \mathrm{Pb}, \mathrm{Cu}, \mathrm{Fe} \\
\mathrm{Mg}, \mathrm{K}, \mathrm{Na}, \mathrm{Zn} \text {, tot } \mathrm{S}\end{array}$ & \multirow[t]{2}{*}{ ICP-OES/Internal procedure } & SFS-EN ISO 17294-2 \\
\hline P total & & ICP \\
\hline BOD & N.A & SFS-EN $1899-1$ or -2 \\
\hline Suspended solids & Calculated/SM $2540 \mathrm{G}$ & SFS-EN 872 \\
\hline Total solids & Calculated/SM $2540 \mathrm{G}$ & N.A \\
\hline
\end{tabular}

Table A2. The $t$-test results for comparing the sum of major compounds and TDS.

\begin{tabular}{|c|c|c|c|c|c|}
\hline \multicolumn{6}{|c|}{$t$-Test: Paired Two Sample for Means } \\
\hline \multicolumn{3}{|c|}{ Mine 1} & \multicolumn{3}{|c|}{ Mine 2} \\
\hline Statistics & $\begin{array}{l}\text { Sum of Major } \\
\text { Compounds }\end{array}$ & TDS & Statistics & $\begin{array}{l}\text { Sum Major } \\
\text { Compounds }\end{array}$ & TDS \\
\hline Mean & 7847.8 & 6274.5 & Mean & 2071.4 & 1765.8 \\
\hline Variance & $1,387,930.9$ & $795,672.7$ & Variance & $384,609.8$ & $253,158.4$ \\
\hline Observations & 43 & 43 & Observations & 25 & 25 \\
\hline Pearson Correlation & 0.2 & & Pearson Correlation & 1.0 & \\
\hline $\begin{array}{l}\text { Hypothesized Mean } \\
\text { Difference }\end{array}$ & 0 & & $\begin{array}{c}\text { Hypothesized Mean } \\
\text { Difference }\end{array}$ & 0 & \\
\hline df & 42 & & $\mathrm{df}$ & 24 & \\
\hline t Stat & 8.0 & & t Stat & 8.9 & \\
\hline $\mathrm{P}(\mathrm{T} \leq \mathrm{t})$ one-tailed & $2.74 \times 10^{-10}$ & & $\mathrm{P}(\mathrm{T} \leq \mathrm{t})$ one-tailed & $2.36 \times 10^{-9}$ & \\
\hline t Critical one-tailed & 1.7 & & t Critical one-tailed & 1.7 & \\
\hline $\mathrm{P}(\mathrm{T} \leq \mathrm{t})$ two-tailed & $5.49 \times 10^{-10}$ & & $\mathrm{P}(\mathrm{T} \leq \mathrm{t})$ two-tailed & $4.73 \times 10^{-9}$ & \\
\hline t Critical two-tailed & 2.0 & & t Critical two-tailed & 2.1 & \\
\hline
\end{tabular}


Table A3. The $t$-test results for comparing $S$ calculated from $S$ compounds and total S.

\begin{tabular}{|c|c|c|c|c|c|}
\hline \multicolumn{6}{|c|}{$t$-Test: Paired Two Sample for Means } \\
\hline \multicolumn{3}{|c|}{ Mine 1} & \multicolumn{3}{|c|}{ Mine 2} \\
\hline Statistics & $S$ calculated & Total S & Statistics & $S$ calculated & Total S \\
\hline Mean & 2161.8 & 1786.1 & Mean & 324.2 & 234.3 \\
\hline Variance & $231,272.9$ & $88,791.68$ & Variance & $10,729.3$ & 4643.6 \\
\hline Observations & 43 & 43 & Observations & 25 & 25 \\
\hline Pearson Correlation & 0.6 & & Pearson Correlation & 0.9 & \\
\hline $\begin{array}{l}\text { Hypothesized Mean } \\
\text { Difference }\end{array}$ & 0 & & $\begin{array}{c}\text { Hypothesized Mean } \\
\text { Difference }\end{array}$ & 0 & \\
\hline $\mathrm{df}$ & 42 & & df & 24 & \\
\hline t Stat & 6.1 & & t Stat & 9.6 & \\
\hline $\mathrm{P}(\mathrm{T} \leq \mathrm{t})$ one-tailed & $1.21 \times 10^{-7}$ & & $\mathrm{P}(\mathrm{T} \leq \mathrm{t})$ one-tailed & $5.33 \times 10^{-10}$ & \\
\hline t Critical one-tailed & 1.7 & & t Critical one-tailed & 1.7 & \\
\hline $\mathrm{P}(\mathrm{T} \leq \mathrm{t})$ two-tailed & $2.42 \times 10^{-7}$ & & $\mathrm{P}(\mathrm{T} \leq \mathrm{t})$ two-tailed & $1.07 \times 10^{-9}$ & \\
\hline t Critical two-tailed & 2.0 & & t Critical two-tailed & 2.1 & \\
\hline
\end{tabular}

Table A4. The $t$-test results for comparing $\mathrm{pH}$ measured in laboratory ( $\mathrm{pH}$ lab) and the $\mathrm{pH}$ measured in situ.

\begin{tabular}{ccc}
\hline \multicolumn{3}{c}{$\boldsymbol{t}$-Test: Paired Two Sample for Means } \\
\hline Statistics & pH Lab & pH in Situ \\
\hline Mean & 5.0 & 8.3 \\
Variance & 2.8 & 1.7 \\
Observations & 34 & 34 \\
Pearson Correlation & 0.7 & \\
Hypothesized Mean Difference & 0 & \\
df & 33 & \\
t Stat & -15.6 & \\
$\mathrm{P}(\mathrm{T} \leq \mathrm{t})$ one-tailed & $4.02 \times 10^{-17}$ & \\
$\mathrm{t}$ Critical one-tailed & 1.7 & \\
$\mathrm{P}(\mathrm{T} \leq \mathrm{t})$ two-tailed & $8.05 \times 10^{-17}$ & \\
$\mathrm{t}$ Critical two-tailed & 2.0 & \\
\hline
\end{tabular}


Table A5. The estimated number of microbial cells in the tested samples from Mine 1 (location Z4) and Mine 2 (location 15) and the efficiency of different methods for cell detachment from the solid particles of samples from the same locations.

\begin{tabular}{|c|c|c|c|c|}
\hline & \multirow[t]{2}{*}{ Method } & \multirow[t]{2}{*}{ Protocol } & \multicolumn{2}{|c|}{$\begin{array}{l}\text { Estimated Total Number of Cells Detached from the Sample } \\
\text { per mL Original Sample (Number of Microscopy Fields) }\end{array}$} \\
\hline & & & Mine 1 Location Z4 & Mine 2 Location 15 \\
\hline 1. & Direct microscopy & $\begin{array}{l}\text { 1. A } 0.01 \mathrm{~mL} \text { sample was mixed with } 0.99 \mathrm{~mL} 0.9 \% \text { sterile } \mathrm{NaCl} \text { and } \\
\text { stained with } 5 \mu \mathrm{g} 4^{\prime} 6 \text {-diamidino-2-phenylindole (DAPI) (SIGMA D9542). } \\
\text { The staining proceeded for } 20 \text { min at ambient temperature, } \\
\text { protected from light. } \\
\text { The stained sample was collected on } 25 \mathrm{~mm} \text { hydrophobic black } 0.2 \mu \mathrm{m} \\
\text { pore size polycarbonate filters (Millipore GTBP02500) by filtration and } \\
\text { excess stain was rinsed from the filters by filtration of } 2 \times 1 \mathrm{~mL} \text { sterile } \\
0.9 \% \mathrm{NaCl} \text { solution. } \\
\text { 3. The filters were mounted on microscopy slides and covered with cover } \\
\text { glasses and examined under UV light using a Zeizz Axio Imager M2 } \\
\text { epifluorescence microscope (Carl Zeiss Microscopy) with } 100 \times \\
\text { magnification. Images were obtained with an AxioCam MRm digital } \\
\text { camera (Carl Zeiss) mounted on the microscope. }\end{array}$ & $* 1.6 \times 10^{8}(30)$ & $* 1.6 \times 10^{8}(30)$ \\
\hline & Direct cell extraction & $\begin{array}{l}\text { 1. A } 1 \mathrm{~mL} \text { sample mixed with } 4 \mathrm{~mL} \text { sterile } 0.9 \% \mathrm{NaCl} \text { solution. } \\
\text { 2. The sample was mixed by vortexing and allowed to settle for } 5 \mathrm{~min} \\
\text { before the supernatant was collected for DAPI staining and } \\
\text { epifluorescence microscopy. } \\
\text { 3. The whole volume of the supernatant was collected on a } 25 \mathrm{~mm} \\
\text { hydrophobic black } 0.2 \mu \mathrm{m} \text { pore size polycarbonate filter (Millipore } \\
\text { GTBP02500) by filtration, where after } 1 \mathrm{~mL} 0.9 \% \mathrm{NaCl} \text { solution } \\
\text { containing } 5 \mu \mathrm{g} \text { DAPI stain was added on top of the filters. The samples } \\
\text { were allowed to stain for } 15-20 \mathrm{~min} \text {, before the stain solution was } \\
\text { removed by filtration, and excess stain was rinsed from the filters by } \\
\text { filtration of } 2 \times 1 \mathrm{~mL} \text { sterile } 0.9 \% \text { NaCl solution. } \\
\text { The filters were examined by epifluorescence microscopy as described } \\
\text { above in Method } 1 \text {. }\end{array}$ & $\begin{array}{l}7.1 \times 10^{5}(7) \\
5.2 \times 10^{5}(5) \\
4.7 \times 10^{5}(8)\end{array}$ & $\begin{array}{l}1.3 \times 10^{5}(7) \\
4.7 \times 10^{4}(2) \\
3.3 \times 10^{5}(4)\end{array}$ \\
\hline 3. & Ultrasonication & $\begin{array}{l}\text { 1. A } 1 \mathrm{~mL} \text { sample mixed with } 4 \mathrm{~mL} \text { sterile } 0.9 \% \mathrm{NaCl} \text { solution. } \\
\text { 2. The samples were submitted to ultrasonication twice for } 2.5 \mathrm{~min}, 25 \mathrm{kHz} \text {, } \\
50 \% \text { (Branson } 2510 \text { ultrasonic cleaner, Marshall scientific) and was mixed } \\
\text { by vortexing in between. } \\
\text { 3. The sample was allowed to settle for a few minutes before the } \\
\text { supernatant was collected for epifluorescence microscopy as described } \\
\text { above in Method } 1 \text { and } 2 \text {. }\end{array}$ & $4.3 \times 10^{5}(6)$ & $2.4 \times 10^{5}(7)$ \\
\hline
\end{tabular}


Table A5. Cont.

\begin{tabular}{|c|c|c|c|c|}
\hline & \multirow[t]{2}{*}{ Method } & \multirow[t]{2}{*}{ Protocol } & \multicolumn{2}{|c|}{$\begin{array}{l}\text { Estimated Total Number of Cells Detached from the Sample } \\
\text { per mL Original Sample (Number of Microscopy Fields) }\end{array}$} \\
\hline & & & Mine 1 Location Z4 & Mine 2 Location 15 \\
\hline 4. & Detergent + ultrasonication & $\begin{array}{l}\text { 1. A } 1 \mathrm{~mL} \text { sample mixed with } 4 \mathrm{~mL} \text { sterile } 0.9 \% \mathrm{NaCl}+0.4 \%(v / v) \text { Tween } \\
20 \text { solution. } \\
\text { 2. The sample was mixed by vortexing. } \\
\text { 3. The samples were submitted to ultrasonication twice and mixed by } \\
\text { vortexing in between. } \\
\text { 4. The solids were pelleted by centrifugation at } 3184 \times g \text { for } 10 \text { min (Mine } 1 \text { ) } \\
\text { or } 2 \text { min (Mine } 2 \text { ) with an Eppendorf } 5810 \mathrm{R} \text { benchtop centrifuge. } \\
\text { 5. The supernatant was collected for microscopy as described above in } \\
\text { Method } 1 \text { and } 2 \text {. }\end{array}$ & $2.8 \times 10^{5}(5)$ & $8.9 \times 10^{5}(5)$ \\
\hline 5. & Detergent + ultrasonication & $\begin{array}{l}\text { 1. A } 1 \mathrm{~mL} \text { sample mixed with } 4 \mathrm{~mL} \text { sterile Milli-Q water }+0.4 \%(v / v) \text { Tween } \\
20 \text { solution. } \\
\text { 2. The sample was mixed by vortexing. } \\
\text { 3. The samples were submitted to ultrasonication twice and mixed by } \\
\text { vortexing in between. } \\
\text { 4. The solids were pelleted by centrifugation at } 3184 \times g \text { for } 10 \mathrm{~min} \text { (Mine } 1 \text { ) } \\
\text { or } 2 \text { min (Mine 2). } \\
\text { 5. The supernatant was collected for microscopy as described above in } \\
\text { Method } 1 \text { and } 2 \text {. }\end{array}$ & $1.5 \times 10^{6}(6)$ & $1.1 \times 10^{6}(8)$ \\
\hline 6. & Detergent + ultrasonication & $\begin{array}{l}\text { 1. A } 1 \mathrm{~mL} \text { sample mixed with } 4 \mathrm{~mL} \text { sterile Milli-Q }+0.04 \%(w / v) \\
\text { Zwittergent } 3-12 \text { solution. } \\
\text { 2. The sample was mixed by vortexing. } \\
\text { 3. Ultrasonication for } 2 \mathrm{~min} \text {. } \\
\text { 4. The solids were pelleted by centrifugation at } 3184 \times g \text { for } 10 \mathrm{~min} \text { (Mine } 1 \text { ) } \\
\text { or } 2 \text { min (Mine } 2 \text { ). } \\
\text { 5. The supernatant was collected for microscopy as described above in } \\
\text { Method } 1 \text { and } 2 \text {. }\end{array}$ & $1.4 \times 10^{5}(4)$ & $1.9 \times 10^{5}(4)$ \\
\hline 7. & Detergent - small volume & $\begin{array}{l}\text { 1. A } 1 \mathrm{~mL} \text { sample mixed with } 4 \mathrm{~mL} \text { sterile } 0.9 \% \mathrm{NaCl}+0.4 \%(v / v) \text { Tween } \\
20 \text { solution. } \\
\text { 2. The sample was mixed by vortexing. } \\
\text { 3. The solids were pelleted by centrifugation at Eppendorf } 5810 \mathrm{R} \text { benchtop } \\
\text { centrifuge at } 3184 \times g \text { for } 10 \text { min (Mine } 1 \text { ) or } 2 \text { min (Mine } 12 \text { ). } \\
\text { 4. The supernatant was collected for microscopy as described above in } \\
\text { Method } 1 \text { and } 2 \text {. }\end{array}$ & $\begin{array}{l}2.0 \times 10^{6}(5) \\
9.9 \times 10^{5}(8)\end{array}$ & $\begin{array}{l}1.5 \times 10^{6}(5) \\
9.4 \times 10^{5}(9)\end{array}$ \\
\hline
\end{tabular}


Table A5. Cont.

\begin{tabular}{|c|c|c|c|c|}
\hline & \multirow[t]{2}{*}{ Method } & \multirow[t]{2}{*}{ Protocol } & \multicolumn{2}{|c|}{$\begin{array}{l}\text { Estimated Total Number of Cells Detached from the Sample } \\
\text { per mL Original Sample (Number of Microscopy Fields) }\end{array}$} \\
\hline & & & Mine 1 Location Z4 & Mine 2 Location 15 \\
\hline 8. & Detergent - small volume & $\begin{array}{l}\text { 1. A } 1 \mathrm{~mL} \text { sample mixed with } 4 \mathrm{~mL} \text { sterile Milli-Q water }+0.4 \%(v / v) \text { Tween } \\
20 \text { solution. } \\
\text { 2. The sample was mixed by vortexing. } \\
\text { 3. The solids were pelleted by centrifugation at } 3184 \times g \text { for } 10 \mathrm{~min} \text { (Mine } 1 \text { ) } \\
\text { or } 2 \text { min (Mine } 12 \text { ). } \\
\text { 4. The supernatant was collected for microscopy as described above in } \\
\text { Method } 1 \text { and } 2 \text {. }\end{array}$ & $1.1 \times 10^{6}(6)$ & $1.1 \times 10^{6}(8)$ \\
\hline & Detergent - small volume & $\begin{array}{l}\text { 1. A } 1 \mathrm{~mL} \text { sample mixed with } 4 \mathrm{~mL} \text { sterile Milli-Q water }+0.04 \%(w / v) \\
\text { Zwittergent } 3-12 \text { solution. } \\
\text { 2. The sample was mixed by vortexing. } \\
\text { 3. The solids were pelleted by centrifugation at } 3184 \times g \text { for } 10 \mathrm{~min} \text { (Mine } 1 \text { ) } \\
\text { or } 2 \text { min (Mine 2). } \\
\text { 4. The supernatant was collected for microscopy as described above in } \\
\text { Method } 1 \text { and } 2 \text {. }\end{array}$ & $1.9 \times 10^{5}(2)$ & $2.4 \times 10^{5}(3)$ \\
\hline 10. & Detergent - medium volume & $\begin{array}{l}\text { 1. A } 1 \mathrm{~mL} \text { sample mixed with } 29 \mathrm{~mL} \text { sterile milli-Q water }+0.4 \%(v / v) \\
\text { Tween } 20 \text { solution. } \\
\text { 2. The sample was mixed by vortexing. } \\
\text { 3. The solids were pelleted by centrifugation at } 3184 \times g \text { for } 10 \mathrm{~min} \text { (Mine } 1 \text { ) } \\
\text { or } 2 \text { min (Mine 2). } \\
\text { 4. The supernatant was collected for microscopy as described above in } \\
\text { Method } 1 \text { and } 2 \text {. }\end{array}$ & $2.6 \times 10^{6}(8)$ & $1.31 \times 10^{6}(8)$ \\
\hline 11. & Detergent - medium volume & $\begin{array}{l}\text { 1. A } 1 \mathrm{~mL} \text { sample mixed with } 29 \mathrm{~mL} \text { sterile Milli-Q water }+0.04 \%(w / v) \\
\text { Zwittergent } 3-12 \text { solution. } \\
\text { 2. The sample was mixed by vortexing. } \\
\text { 3. The solids were pelleted by centrifugation at } 3184 \times g \text { for } 10 \mathrm{~min} \text { (Mine } 1 \text { ) } \\
\text { or } 2 \text { min (Mine } 2 \text { ). } \\
\text { 4. The supernatant was collected for microscopy as described above in } \\
\text { Method } 1 \text { and } 2 \text {. }\end{array}$ & $2.6 \times 10^{6}(8)$ & $1.8 \times 10^{6}(8)$ \\
\hline
\end{tabular}


Table A5. Cont.

\begin{tabular}{|c|c|c|c|c|}
\hline & \multirow[t]{2}{*}{ Method } & \multirow[t]{2}{*}{ Protocol } & \multicolumn{2}{|c|}{$\begin{array}{l}\text { Estimated Total Number of Cells Detached from the Sample } \\
\text { per mL Original Sample (Number of Microscopy Fields) }\end{array}$} \\
\hline & & & Mine 1 Location Z4 & Mine 2 Location 15 \\
\hline 12. & Serial extraction with Milli-Q water & $\begin{array}{l}\text { 1. A } 1 \mathrm{~mL} \text { sample was mixed with } 349 \mathrm{~mL} \text { Milli-Q water. } \\
\text { 2. The sample was mixed by manual shaking for } 2 \mathrm{~min} \text { and allowed to } \\
\text { settle for } 30 \mathrm{~min} \text {. } \\
\text { 3. The decanted supernatant was centrifuged at } 3184 \times \mathrm{g} \text { for } 10 \mathrm{~min} \\
\text { (Mine } 1 \text { ) or } 2 \text { min (Mine } 2 \text { ). } \\
\text { 4. The supernatant was collected for cell enumeration by microscopy } \\
\text { (sample A). } \\
\text { 5. A second extraction was performed on the solid sample (step 2) by } \\
\text { mixing with } 150 \mathrm{~mL} \text { Milli-Q water. } \\
\text { 6. The sample was manually mixed for } 2 \text { min and allowed to settle for } \\
\text { 30 min. } \\
\text { 7. The supernatant was decanted and centrifuged at } 3184 \times g \text { for } 10 \mathrm{~min} \\
\text { (Mine } 1 \text { ) or } 2 \text { min (Mine } 2 \text { ). } \\
\text { 8. The second supernatant was collected for cells (sample B). } \\
\text { 9. The supernatants A and B were treated separately and prepared for } \\
\text { microscopy as described above in Method } 1 \text { and } 2 \text {. }\end{array}$ & $\begin{array}{c}\text { A: } 3.2 \times 10^{6}(9) \\
\text { B: } 4.3 \times 10^{6}(7) \\
\text { Total number of extracted } \\
\text { cells }(A+B): 7.4 \times 10^{6}(16)\end{array}$ & $\begin{array}{c}\text { A: } 2.2 \times 10^{6}(7) \\
\text { B: } 3.1 \times 10^{6}(5) \\
\text { Total number of extracted } \\
\text { cells }(A+B): 5.3 \times 10^{6}(12)\end{array}$ \\
\hline & Serial extraction with detergent & $\begin{array}{l}\text { 1. A } 1 \mathrm{~mL} \text { sample was mixed with } 349 \text { Milli-Q water }+0.4 \%(v / v) \text { Tween } 20 \text {. } \\
\text { 2. The sample was mixed by manual shaking for } 2 \text { min and allowed to } \\
\text { settle for } 30 \text { min. } \\
\text { 3. The decanted supernatant was centrifuged at } 3184 \times g \text { for } 10 \mathrm{~min} \\
\text { (Mine } 1 \text { ) or } 2 \text { min (Mine } 2 \text { ). } \\
\text { 4. The supernatant was collected for cell enumeration by microscopy } \\
\text { (sample A). } \\
\text { 5. A second extraction was performed on the solid sample (step } 2 \text { ) by } \\
\text { mixing with } 150 \text { mL Milli-Q water }+0.4 \%(v / v) \text { Tween } 20 \text {. } \\
\text { 6. The sample was manually mixed for } 2 \text { min and allowed to settle for } \\
\text { 30 min. } \\
\text { 7. The decanted supernatant was centrifuged at } 3184 \times g \text { for } 10 \text { min } \\
\text { (Mine } 1 \text { ) or } 2 \text { min (Mine } 2 \text { ). } \\
\text { 8. The second supernatant was collected for cells (sample B). } \\
\text { 9. The supernatants A and B were treated separately and prepared for } \\
\text { microscopy as described above in Method } 1 \text { and } 2 \text {. }\end{array}$ & $\begin{array}{c}\text { A: } 8.0 \times 10^{6}(10) \\
\text { B: } 7.37 \times 10^{7}(8) \\
\text { Total number of extracted } \\
\text { cells }(A+B): 4.3 \times 10^{6}(18)\end{array}$ & $\begin{array}{c}\text { A: } 1.1 \times 10^{7}(8) \\
\text { B: } 6.5 \times 10^{6}(8) \\
\text { Total number of extracted } \\
\text { cells }(\mathrm{A}+\mathrm{B}): 1.8 \times 10^{7}(16)\end{array}$ \\
\hline
\end{tabular}

* Due to the high concentration of solids in the sample, the number of fluorescent cells remained uncertain. Based on the visible cells the numbers were estimated to be at least $1.6 \times 10^{8}$ cells $\mathrm{mL}^{-1}$ sample. 
Table A6. Extraction of microbial DNA from samples from Mine 1 (location 24) and Mine 2 (location 15) using commercial DNA extraction kits. In order to test the efficiency of extracting DNA from the solid particles of the samples, the samples were spiked with a culture solution of Desulfovibrio desulfuricans E-95573T cells, a sulfate reducing bacterium (SRB). The amount of DNA in the SRB solution was tested by extracting the DNA from $10 \mathrm{~mL}$ of culture by first collecting the SRB cells by centrifugation for $10 \mathrm{~min}, 3184 \times g$, on an Eppendorf 5810R benchtop centrifuge, and extracting the DNA from the cell pellet using the Macherey-Nagel Soil DNA extraction kit with lysis buffer 1 and SX solution, as recommended by the manufacturer. The DNA extraction was done in duplicate. The amount of DNA was measured using the Qbit fluorometer (Thermo Fisher Scientific). The amount of DNA obtained from $10 \mathrm{~mL}$ of SRB culture solution was approximately 180 ng mL ${ }^{-1}$ culture. The limit of detection of DNA with the Qubit fluorometer was $0.025 \mathrm{ng} / 5 \mathrm{~mL}$ sample (i.e., bd = below detection).

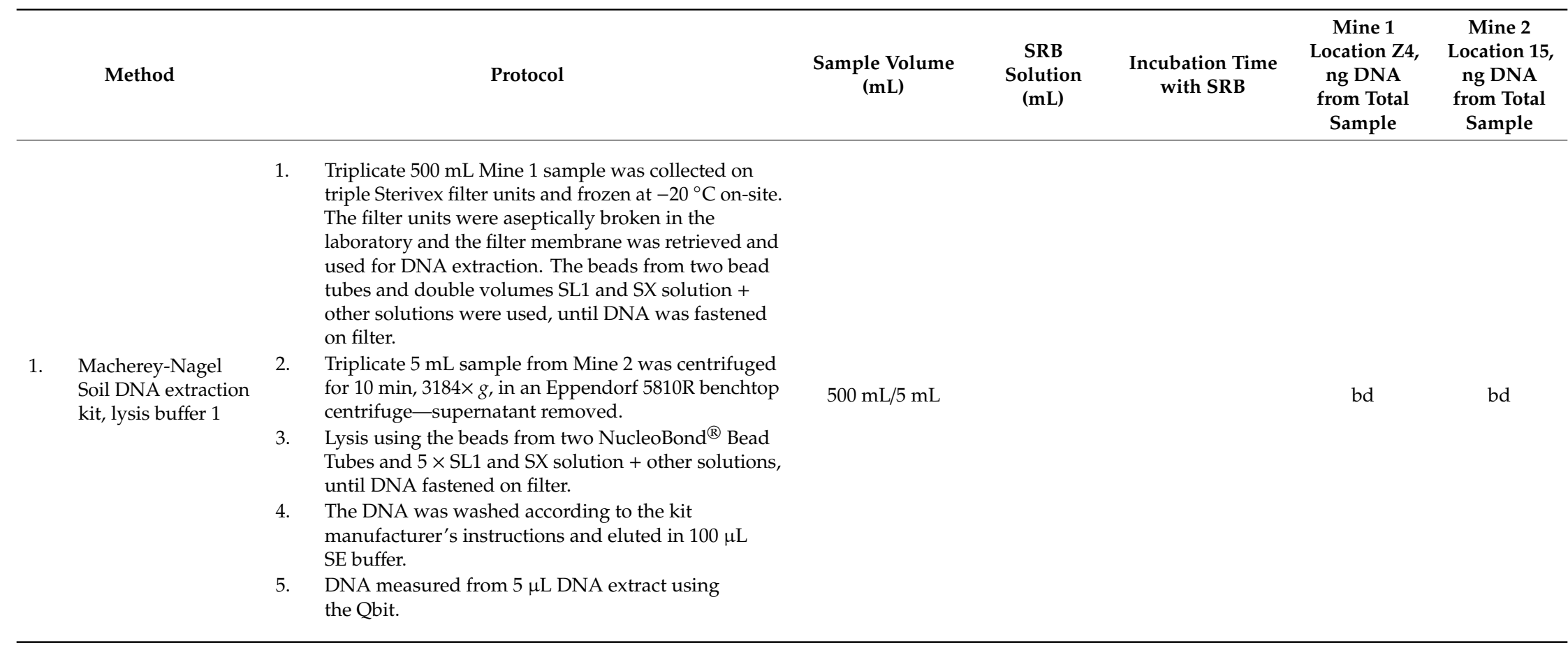


Table A6. Cont.

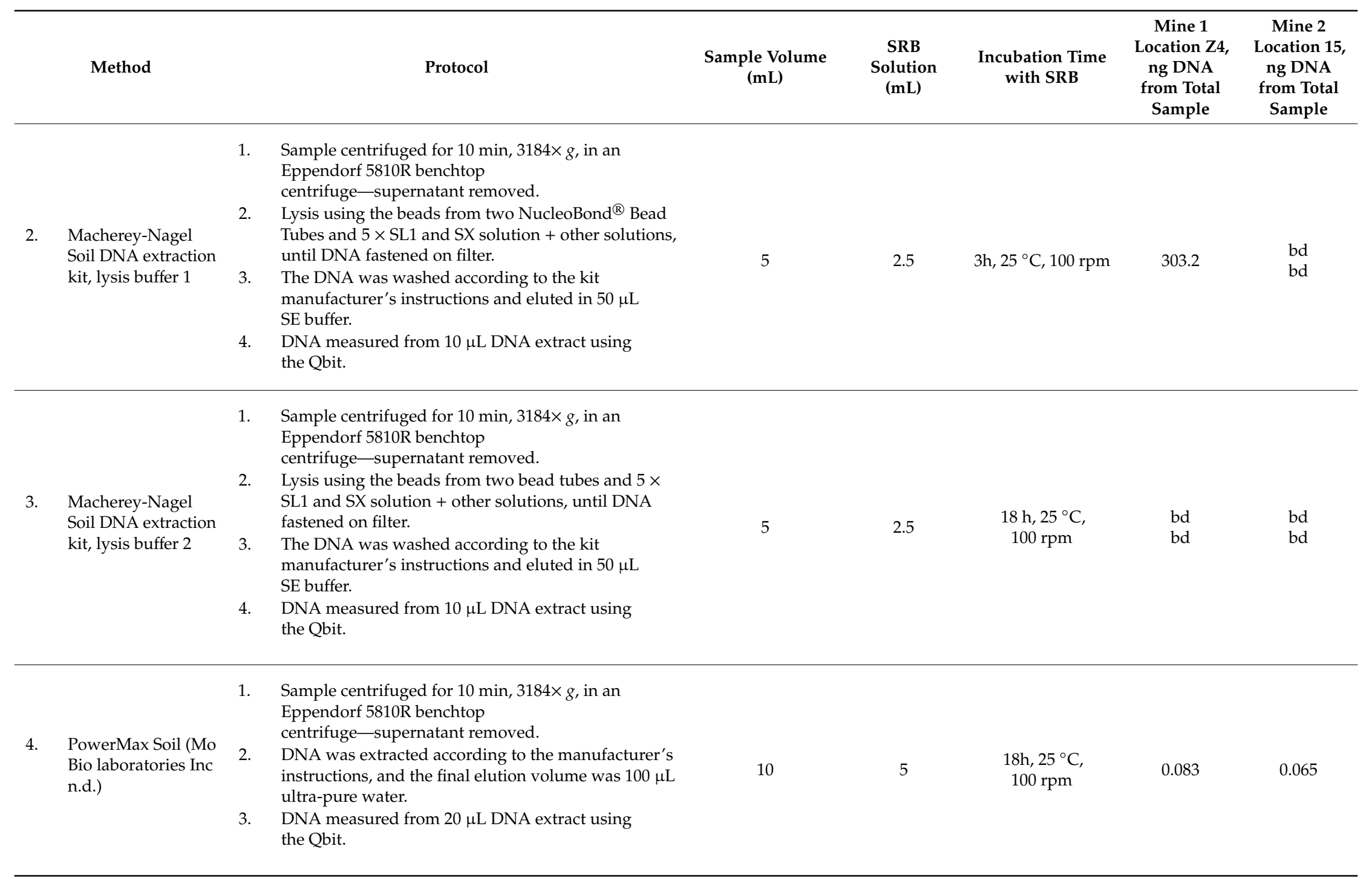


Table A6. Cont.

\begin{tabular}{|c|c|c|c|c|c|c|c|}
\hline & Method & Protocol & $\begin{array}{c}\text { Sample Volume } \\
(\mathrm{mL})\end{array}$ & $\begin{array}{l}\text { SRB } \\
\text { Solution } \\
(\mathrm{mL})\end{array}$ & $\begin{array}{l}\text { Incubation Time } \\
\text { with SRB }\end{array}$ & $\begin{array}{c}\text { Mine } 1 \\
\text { Location Z4, } \\
\text { ng DNA } \\
\text { from Total } \\
\text { Sample }\end{array}$ & $\begin{array}{c}\text { Mine } 2 \\
\text { Location 15, } \\
\text { ng DNA } \\
\text { from Total } \\
\text { Sample }\end{array}$ \\
\hline 5. & $\begin{array}{l}\text { ZR SoilMicrobe } \\
\text { DNA Midiprep } \\
\text { (Zymo Research } \\
\text { Corp. n.d.) }\end{array}$ & $\begin{array}{l}\text { 1. Sample centrifuged for } 10 \mathrm{~min}, 3184 \times g \text {, in an } \\
\text { Eppendorf } 5810 \mathrm{R} \text { benchtop } \\
\text { centrifuge-supernatant removed. } \\
\text { The pellet was suspended in } 2 \times 3 \mathrm{~mL} \text { lysis buffer } \\
\text { and transferred to a ZR SOilMicrobe DNA Midiprep } \\
\text { Bashing Bead Tube. } \\
\text { 3. The DNA extraction continued according to the } \\
\text { manufacturer's protocol, and the DNA was eluted in } \\
100 \mu \mathrm{L} \text { elution buffer. } \\
\text { The DNA concentration was measured from } 20 \mu \mathrm{L} \\
\text { DNA extract using the Qbit. }\end{array}$ & 5 & 2.5 & $\begin{array}{c}18 \mathrm{~h}, 25^{\circ} \mathrm{C} \\
100 \mathrm{rpm}\end{array}$ & 0.57 & 0.55 \\
\hline 6. & $\begin{array}{l}\text { NucleoBond }{ }^{\circledR} \text { RNA } \\
\text { soil + DNA Kit } \\
\text { (Macherey-Nagel) }\end{array}$ & $\begin{array}{l}\text { 1. Sample centrifuged for } 10 \mathrm{~min}, 3184 \times g \text {, in an } \\
\text { Eppendorf } 5810 \mathrm{R} \text { benchtop } \\
\text { centrifuge-supernatant removed } \\
\text { 2. The beads of four NucleoBond }{ }^{\circledR} \text { Bead Tubes were } \\
\text { added to each extraction } \\
\text { 3. A } 3.2 \mathrm{~mL} \text { sample of } \mathrm{E} 1 \text { buffer, } 400 \mu \mathrm{L} \text { of OPT buffer } \\
\text { and } 400 \mu \mathrm{L} \text { of phenol:chloroform:isoamyl alcohol was } \\
\text { added to each sample, followed by a } 2 \text { min vortexing. } \\
\text { 4. The extraction proceeded as recommended by } \\
\text { the manufacturer. } \\
\text { 5. The DNA was eluted in } 100 \mu \mathrm{L} \text { elution buffer. } \\
\text { 6. The DNA concentration was measured from } 20 \mu \mathrm{L} \\
\text { DNA extract using the Qbit. }\end{array}$ & 2.5 & 2.5 & $\begin{array}{c}18 \mathrm{~h}, 25^{\circ} \mathrm{C} \\
100 \mathrm{rpm}\end{array}$ & bd & 1.25 \\
\hline
\end{tabular}




\section{References}

1. Tiwary, R.K.; Singh, D.B.; Tewary, B.K. Mine Water Quality and Its Management in Indian Metalliferrous Mines. Water Qual. Quant. Min. 2000, 326, 660-671.

2. Environment and Climate Change Canada. Technical Guidance for Environmental Effects Monitoring (EEM). 2012. Available online: https://www.ec.gc.ca/esee-eem/default.asp?lang=En\&n=aec7c481-1 (accessed on 20 March 2020).

3. The European Commission. Directive 2010/75/EU of the European Parliament and of the Council. Off. J. Eur. Union L 2010, 334, 17-119.

4. Opitz, J.; Timms, W. Mine Water Discharge Quality-a Review of Classification Frameworks. In Proceedings of the IMWA 2016 Mining Meets Water-Conflicts and Solutions, Leipzig, Germany, 11-15 July 2016.

5. Myers, M.D. Handbooks for Water-Resources Investigations: National Field Manual for the Collection of Water-Quality Data; USGS: Reston, Virginia, 2006.

6. Heikkinen, P.; Noras, P.; Salminen, R. Mine Closure Handbook. Environmental Techniques for the Extractives Industries; Vammalan Kirjapaino Oy: Helsinki, Finland, 2008.

7. Fowlie, P.; Hart, D.; Turle, R. Guidance Document for the Sampling and Analysis of Metal Mining Effluents: Final Report. 2001. Available online: http://publications.gc.ca/collections/Collection/En49-24-1-39E.pdf (accessed on 8 March 2020).

8. Punkkinen, H.; Räsänen, L.; Mroueh, U.-M.; Korkealaakso, J.; Luoma, S.; Kaipainen, T.; Backnäs, S.; Turunen, K.; Hentinen, K.; Pasanen, A.; et al. Guidelines for Mine Water Management; VTT Technical Research Centre of Finland Ltd.: Espoo, Finland, 2016.

9. Farrokhpay, S.; Zanin, M. An Investigation into the Effect of Water Quality on Froth Stability. Adv. Powder Technol. 2012, 23, 493-497. [CrossRef]

10. Ikumapayi, F.K.; Makitalo, M.; Johansson, B.; Hanumantha Rao, K. Recycling Process Water in Complex Sulphide Ore Flotation: Effect of Calcium and Sulphate on Sulfide Minerals Recovery. In Proceedings of the 26th International Mineral Processing Congress (IMPC 2012), New Delhi, India, 24-28 September 2012.

11. Johnson, N. Issues in Maximisation of Recycling of Water in a Mineral Processing Plant. In Proceedings of the Water in Mining 2003, Brisbane Australia, 13-15 October 2003; AusIMM: Carlton, Australia; pp. 239-246.

12. Rao, S.R.; Finch, J.A. A Review of Water Re-Use in Flotation. Miner. Eng. 1989, 2, 65-85. [CrossRef]

13. Levay, G.; Smart, R.; Skinner, W. The Impact of Water Quality on Flotation Performance. Saimm. J. 2001, 101, 69-76.

14. Liu, W.; Moran, C.J.; Vink, S. A Review of the Effect of Water Quality on Flotation. Miner. Eng. 2013, 53, 91-100. [CrossRef]

15. Madrid, Y.; Zayas, Z.P. Water Sampling: Traditional Methods and New Approaches in Water Sampling Strategy. TrAC Trends Anal. Chem. 2007, 26, 293-299. [CrossRef]

16. Mohapatra, D.P.; Kirpalani, D.M. Process Effluents and Mine Tailings: Sources, Effects and Management and Role of Nanotechnology. Nanotechnol. Environ. Eng. 2016, 2, 1. [CrossRef]

17. Dharmappa, H.B.; Sivakumar, M.; Singh, R.N. Wastewater Characteristics, Management and Reuse in Mining and Mineral Processing Industries. Wastewater Recycl. Reuse Reclam. 1998, 1, 10.

18. Kinnunen, P.; Miettinen, H.; Bomberg, M. Review of Potential Microbial Effects on Flotation. Minerals 2020, 10, 533. [CrossRef]

19. Gadd, G.M. Metals, Minerals and Microbes: Geomicrobiology and Bioremediation. Microbiology 2010, 156, 609-643. [CrossRef] [PubMed]

20. Greet, C.J. Chapter 1-The Eureka Mine-An Example of How to Identify and Solve Problems in a Flotation Plant. In Flotation Plant Optimisation: A Metallurgical Guide to Identifying and Solving Problems in Flotation Plants; AusIMM: Victoria, Australia, 2010; pp. 1-33.

21. Minkkinen, P.O.; Esbensen, K.H. Grab vs. Composite Sampling of Particulate Materials with Significant Spatial Heterogeneity-A Simulation Study of "Correct Sampling Errors". Anal. Chim. Acta 2009, 653, 59-70. [CrossRef]

22. Miranda-Trevino, J.C.; Pappoe, M.; Hawboldt, K.; Bottaro, C. The Importance of Thiosalts Speciation: Review of Analytical Methods, Kinetics, and Treatment. Crit. Rev. Environ. Sci. Technol. 2013, 43, 2013-2070. [CrossRef] 
23. Kuyucak, N. Management of Thiosalts in Mill Effluents by Chemical Oxidation or Buffering in the Lime Neutralization Process. Miner. Eng. 2014, 60, 41-50. [CrossRef]

24. Vongporm, Y. Thiosalt Behaviour in Aqueous Media. Ph.D. Thesis, Memorial University of Newfoundland, Saint John's, NL, Canada, 2008; pp. 26-36.

25. Wasserlauf, M.; Dutrizac, J.E. Canmet's Project on the Chemistry, Generation and Treatment of Thiosalts in Milling Effluents. Can. Metall. Q. 1984, 23, 259-269. [CrossRef]

26. Bıçak, Ö; Ekmekçi, Z.; Can, M.; Öztürk, Y. The Effect of Water Chemistry on Froth Stability and Surface Chemistry of the Flotation of a Cu-Zn Sulfide Ore. Int. J. Miner. Process. 2012, 102-103,, 32-37.

27. Öztürk, Y.; Bıçak, Ö.; Özdemir, E.; Ekmekçi, Z. Mitigation Negative Effects of Thiosulfate on Flotation Performance of a Cu-Pb-Zn Sulfide Ore. Miner. Eng. 2018, 122, 142-147. [CrossRef]

28. Evdokimova, G.A.; Gershenkop, A.S.; Fokina, N.V. The Impact of Bacteria of Circulating Water on Apatite-Nepheline Ore Flotation. J. Environ. Sci. Health Part A 2012, 47, 398-404. [CrossRef] [PubMed]

29. Bomberg, M.; Miettinen, H.; Musuku, B.; Kinnunen, P. First Insights to the Microbial Communities in the Plant Process Water of the Multi-Metal Kevitsa Mine. Res. Microbiol. Revis. 2020. in Press. [CrossRef]

30. Sagripanti, J.L.; Hülseweh, B.; Grote, G.; Voß, L.; Böhling, K.; Marschall, H.J. Microbial Inactivation for Safe and Rapid Diagnostics of Infectious Samples. Appl. Environ. Microbiol. 2011, 77, 7289-7295. [CrossRef]

31. Makhija, R.; Hitchen, A. The Titrimetric Determination of Sulphate, Thiosulphate and Polythionates in Mining Effluents. Anal. Chim. Acta 1979, 105, 375-382. [CrossRef]

32. SFS-EN ISO 10304-3:en. Water Quality: Determination of Dissolved Anions by Liquid Chromatography of Ions. Part 3: Determination of Chromate, Iodide, Sulfite, Thiocyanate and Thiosulfate (ISO 10304-3:1997). Available online: https:/sales.sfs.fi/fi/index/tuotteet/SFS/CENISO/ID2/1/197428.html.stx (accessed on 20 March 2020).

33. Whaley-Martin, K.; Marshall, S.; Nelson, T.E.C.; Twible, L.; Jarolimek, C.V.; King, J.J.; Apte, S.C.; Warren, L.A. A Mass-Balance Tool for Monitoring Potential Dissolved Sulfur Oxidation Risks in Mining Impacted Waters. Mine Water Environ. 2020, 39, 291-307. [CrossRef]

Publisher's Note: MDPI stays neutral with regard to jurisdictional claims in published maps and institutional affiliations.

(C) 2020 by the authors. Licensee MDPI, Basel, Switzerland. This article is an open access article distributed under the terms and conditions of the Creative Commons Attribution (CC BY) license (http://creativecommons.org/licenses/by/4.0/). 